\title{
Magmatism and early-Variscan continental subduction in the northern Gondwana margin recorded in zircons from the basal units of Galicia, NW Spain
}

\author{
Jacobo Abati ${ }^{1, \dagger}$, Axel Gerdes ${ }^{2}$, Javier Fernández Suárez ${ }^{1}$, Ricardo Arenas ${ }^{1}$, Martin J. Whitehouse ${ }^{3}$, and \\ Rubén Díez Fernández' \\ ${ }^{1}$ Departamento de Petrología y Geoquímica and Instituto de Geología Económica, Universidad Complutense and Consejo Superior \\ de Investigaciones Cientificas, 28040 Madrid, Spain \\ ${ }^{2}$ Institut für Geowissenschaften, Mineralogie, Johann Wolfgang Goethe-Universitat Frankfurt am Main, Altenhöferallee 1, D-60438 \\ Frankfurt am Main, Germany \\ ${ }^{3}$ Swedish Museum of Natural History, Stockholm, Sweden \\ ${ }^{4}$ Departamento de Geologia, Universidad de Salamanca, 37008 Salamanca, Spain
}

\section{ABSTRACT}

In situ uranium-lead dating (LA-SF-ICPMS and SIMS) and Lu-Hf isotope analyses (LA-MC-ICP-MS) of zircon from eclogite facies rocks from the basal units of the Variscan Belt in Galicia constrain their magmatic and metamorphic evolution and give some clues about the nature and origin of the involved basement. The samples studied are two felsic gneisses, two eclogites, and one eclogitic gneiss of intermediate composition (metatonalite). Oscillatory-zoned zircon cores from the felsic samples gave a main clustering of U-Pb ages at $493 \pm 2$ and $494 \pm 2 \mathrm{Ma}$, and some older ages that represent inherited cores. Zircon grains from the intermediate and one of the mafic rocks show no inherited cores and yielded ages of $494 \pm 3$ and $498 \pm 6 \mathrm{Ma}$, respectively, interpreted as time of protolith crystallization. Variably developed homogeneous zircon rims in one felsic gneiss yielded an age of $372 \pm 3 \mathrm{Ma}$, and very tiny zircons of one eclogite gave $350 \pm 2 \mathrm{Ma}$, both of which we interpret as metamorphic ages.

The new age data demonstrate that the calc-alkaline magmatic suite described in the basal unit is ca. 20 Ma older than the alkaline to peralkaline plutonic suite of the same unit (dated at $472 \pm 2$ Ma; Rodríguez et al., 2007), and thus probably represents a distinct geologic event. Overgrowth rims are interpreted as metamorphic on the basis of their $\mathrm{Lu} / \mathrm{Hf}$ and $\mathrm{Th} / \mathrm{U}$ ratios. The $372 \pm 3$ age is considered as dating the high-pressure (high-P)

'E-mail: abati@ge•.ucm.es metamorphism, and is essentially in agreement with previous Ar-Ar and Rb-Sr data. This high-P metamorphism marks the initial early-Variscan subduction of the Gondwana margin. The inherited zircon ages and $\mathrm{Hf}$ isotopic composition of zircons point to a considerable input of crustal material with WestAfrican Craton provenance to the felsic magma.

\section{INTRODUCTION}

The basal units of the allochthonous complexes of NW Iberian Massif, together with comparable terranes throughout the Variscan Belt of Europe, are interpreted as a part of the most external edge of the north Gondwana margin (Martínez Catalán et al., 1996). The ensemble of terranes that originated around this margin is known as peri-Gondwanan terranes. These terranes formed an especially active geological realm during the Neoproterozoic and the whole of the Paleozoic. In general terms, they record Neoproterozoic to Cambrian arc magmatism, followed by a rifting episode around the Cambro-Ordovician boundary (Nance et al., 2008). The basal units in Galicia have abundant in rusive rocks, which have been grouped in two magmatic suites-calc-alkaline and alkaline to peralkaline (Rodríguez Aller, 2005). Based on geochemical and age data, the origins of both magmatic suites have been interpreted with the development of a post-collisional tectonic regime. The calc-alkaline plutons have been explained as resulting from mixing between crustal and basic magmas and the alkaline plutons from fractional crystallization in a closed system (Rodríguez Aller, 2005). The age of the peralkaline bodies is tightly constrained by U-Pb thermal ionization mass spectrometry TIMS, but the age of the calc-alkaline igneous bodies is not so well constrained (Fig. 1). One of the objectives of this work is to obtain more precise ages for the calc-alkaline magmatism in order to test for possible age differences between both magmatic suites, and to determine to what extent this magmatism is representative of the peri-Gondwanan terranes.

Another first-order issue concerning the geodynamic evolution of the European Variscan Belt is the timing of the onset of subduction of the Gondwana margin. The initiation of continental subduction terminated the protracted period of subduction, rifting of terranes from and accretion to the Gondwana margin to a continental collision involving significant crustal thickening. For that reason, determining the age of the high-pressure metamorphism of the terranes immediately below the ophiolites, which represent the most external margin of north Gondwana, has been a major goal of geological research in the Variscan Belt. At present, the age of this metamorphism in western Europe is well constrained by Ar-Ar and Rb-Sr ages between 370 and 360 Ma (Santos Zalduegui etal., 1995; Rodrígue zet al., 2003; Bosse et al., 2005), obtained from eclogitic white micas. An additional step would be refining the data using other isotopic systems in different lithologies, to reduce the analytical uncertainty and to confirm that these ages late the high-pressure metamorphism and are not, for instance, cooling ages. It is also desirable to obtain ages in different geographic areas, to allow for more precise terrane correlations and to test for diachronism in

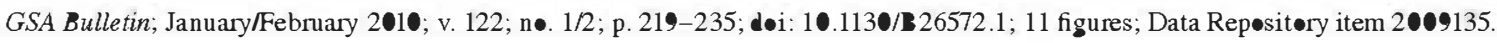




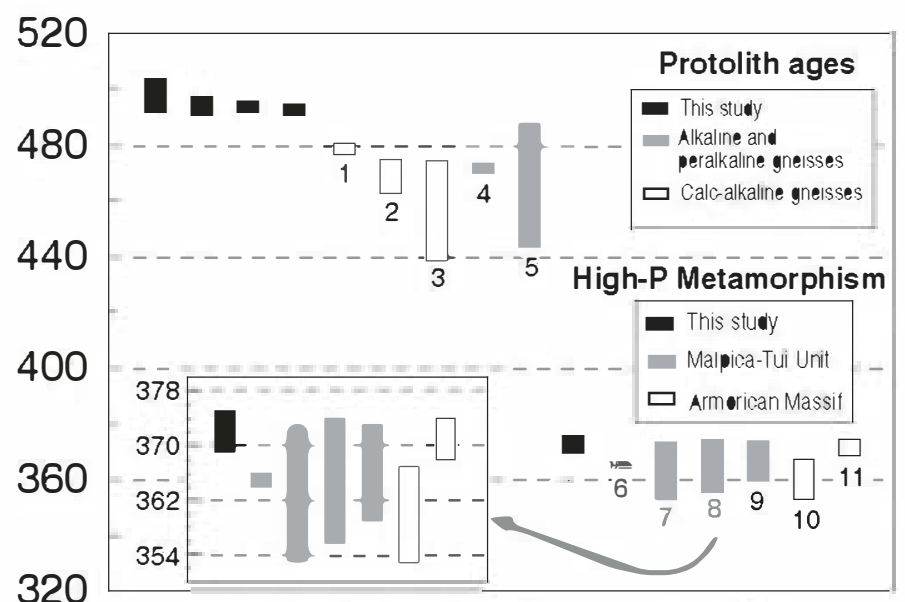

(1) $479 \pm 2(\cup-P b)$; Santos Zalduegui et al., 1995

(2) $469 \pm 6$ (WR Rb-Sr); García Garzón et al., 1981

(3) $457 \pm 18$ (WR Rb-Sr): van Calsteren et al., 1979

(4) $472 \pm 2$ (U-Pb ID-TIMS); Rodríguez et al., 2007

(5) $466 \pm 22$ (Pb-Pb); Montero et al., 1998

(6) $365 \pm 1$ (Ar-Ar); Rodríguez et al., 2003

(7) $363 \pm 10$ (Ar-Ar); Rodríguez et al., 2003

(8) $365 \pm$ ? (Rb-Sr model); Santos Zalduegui et al., 1995

(9) $366 \pm$ ? (Rb-Sr model); van Calsteren et al., 1979

(10) $360 \pm 7$ (11 Ar-Ar ages); Bosse et al., 2005

(11) $371 \pm 3$ (1 Ar-Ar age); Bosse et al., 2005

Figure 1. Summary of the radiometric ages obtained in this study and comparison with the published ages for the equivalent terranes (basal units) in the allochthonous complexes of the NW Iberian Massif and the Armorican Massif. Abbreviations: Zrn-zircon; WR-whole rock; rli-regression line interception; model-Rb-Sr model ages; ID-TIMS-isotope dilution-thermal ionization mass spectrometry. We excluded old data with very high uncertainties.

the convergence between Laurussia and Gondwana. The main part of this work deals with in situ U-Pb secondary ion mass spectromery (SIMS) and combined U-Pb and Lu-Hf laser ablation-sector field-inductively coupled plasma-mass spectrometry (LA-SF-ICP-MS) analyses of magmatic and metamorphic zircon grains from orthogneiss and eclogite from two different basal units (Malpica and Agualada, two of the units structurally below the ophiolites) of the allochthonous complexes of the NW Iberian Massif. Zircon from one of the samples shows complex zoning, such as cores with oscillatory growth zoning and thick overgrowth rims (interpreted as metamorphic), which have permitted precise dating of two distinct events of zircon growth. In combination with existing data, our new zircon ages better constrain the timing of the initial subduction of continental rocks in early Variscan times and the tectonothermal evolution of the basal units. Furthermore, the inherited zircon age spectra and Lu-Hf isotopic compositions provide hints as to the nature of the basement to the sediments of the basal units and from which the melts were probably extracted.

\section{GEOLOGIC SETTING}

The northwestern corner of the Iberian Massif is located at the hinge zone of the Ibero-Annorican Arc, and includes the Spanish regions of Galicia and Asturias, as well as Trás-os-Montes, in northern Portugal (Fig. 2). The region preserves relicts of oceanic reahns, interpreted as part of the ocean that once separated the early Paleozoic continents, the Rheic Ocean, and record large amounts of orogenic shortening. The basement of NW Iberia consists of metamorphic rocks ranging from very low to high grade, and plutonic rocks. Autochthonous and allochthonous terranes can be distinguished. The autochthon consists of a thick metasedimentary sequence inferred to have been deposited on the northern Gondwanan margin during late Neoproterozoic and Paleozoic times. The allochthon is the remnant of a huge and stucturally complex nappe stack preserved in the core of late Variscan synforms. It consists of exotic terranes, many of peri-Gondwanan derivation, with several that bear the imprint of Paleozoic subduction. Each of the allochthonous units have local names, but they can often be cor- related among the five existing allochthonous complexes of Cabo Ortegal, Órdenes, and Malpica-Tui in Galicia (Fig. 2), and Bragança and Morais in Portugal. They are classified in three groups according to their structural position in the nappe pile and also to their origin:

(1) The basal units are inferred to have been derive from distal parts of the Gondwanan continental margin, and record an initial high-pressure metamorphic event (Martínez Catalán etal., 1996; Arenas et al., 1997).

(2) The ophiolitic units, in intermediate position, are pieces of oceanic lithosphere that are thought to represent the suture of the Rheic Ocean (Arenas et al., 2007).

(3) The upper units derive from a magmatic arc that is thought to have developed at the northem margin of Gondwana, and which was subsequently pulled apart by slab rollback, and drifted away opening a backarc that widened into and gave rise to the Rheic Ocean (Abati et al., 1999; Martínez Catalán et al., 2002; Abati et al., 2003).

The geologic features, geodynamic evolution, and significance of these units are described in detail elsewhere (e.g., Martínez Catalán et al., 2002, 2007).

\section{The Basal Units}

Because the basal units are not separated from the parauthochthon by ophiolites, they are assumed to belong to Gondwana, and because the ophiolitic units overlie them, they are viewe as fragments of the most external edge of the Gondwanan continental margin. There are several basal units that appear in the different complexes of the NW Iberian Massif. In Galicia they include the Espasante Unit, in the eastem border of the Cabo Ortegal Complex; the Lalín, Forcarei, Santiago, and Agualada units in the southern and western rims of the Órdenes Complex; and the elongated MalpicaTui Unit of western Galicia (Fig. 2). Some of the units are separated by relatively large distances and show different characteristics, but their structural reconstruction indicates that they were a coherent and continuous sheet (Martínez Catalán et al., 2007) of continental and, in some cases, transitional to oceanic lithosphere (Rodríguez Aller, 2005). The early-Variscan, high-P metamorphism affecting the basal units has been interpreted as the result of subduction under the southern margin of Laurussia at the beginning of the Variscan collision (Martínez Catalán et al., 1996; Arenas et al., 1997). They were subsequently accreted to the Variscan orogenic wedge as a thin, imbricated tlırust sheet. 
Figure 2. Geologic map of Galicia showing the parautochthon, the allochthonous units, and the local names of the basal units.

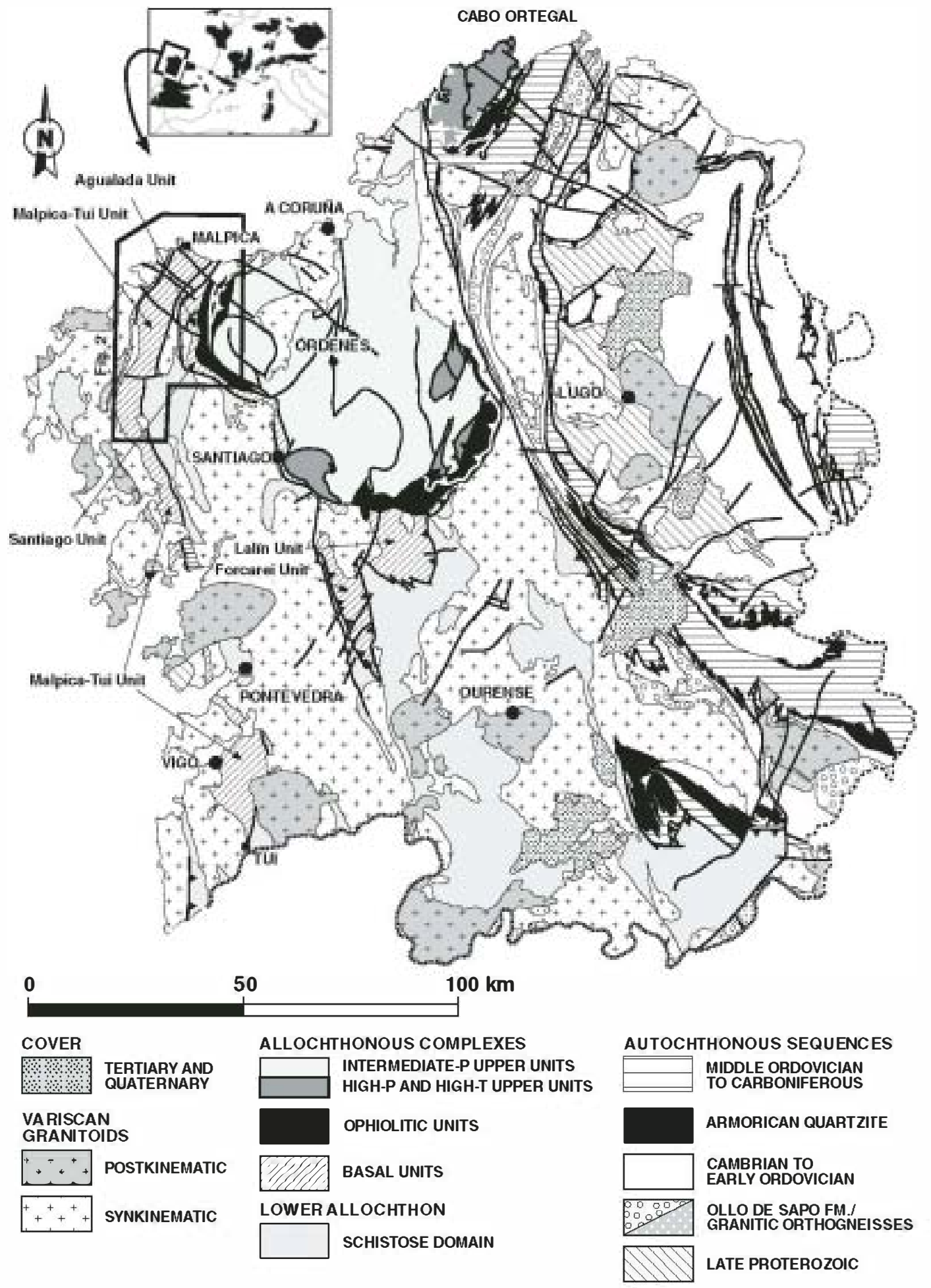

The polarity of the subduction has been deduced by the presence of a pressure gradient along the sheet, where pressure increases from east to west indicating a west-directed polarity in present coordinates (Martínez Catalán et al., 1996), and the paleodip of the subduction zone has been estimate $15^{\bullet}$ to $20^{\bullet}$ from the pressure- temperature (P-T) conditions and themal modeling (Alcock et al., 2005). Peak pressure ranges from 1.0 to $1.65 \mathrm{GPa}$ in the Órdenes Complex to more than $2.0 \mathrm{GPa}$ in the Malpica-Tui Unit. The evidence for subduction includes a great variety of high-P mineral associations developed in different lithologies, more or less retrograded during subsequent synkinematic amphibolite to greenschist facies metamorphism. The best developed and preserved high-P mineral associations are in the westem and higher pressure outcrops, corresponding to the Malpica-Tui unit, where different types of eclogite, jadeite-bearing orthogneiss, phengite-chloritoid-glaucophane 
metapelites, and blueschist are common (Gil Ibarguchi and Ortega Gironés, 1985; Gil Ibargucbi, 1995; Arenas et al., 1995, 1997; Rubio Pascual et al., 2002; Rodríguez et al., 2003; Rodríguez Aller, 2005; López Carmona et al., 2007). These terranes can be correlated with similar terranes in the central European massifs; thus, basal units with late Devonianearly Carboniferous high-pressure and low- to intermediate-temperature metamorphism are found from Spain and Portugal in the west to eastern Europe, like the Kaczawa complex in the Polish Sudetes (Kryza et al., 1990).

The basal units consist of metasediments altemating with igneous rocks. The metasediments include phyllite, schist, metagraywacke, and paragneiss, normally with high plagioclase content. Schists with porphyroblasts of albite and oligoclase are common. Quartzite, carbonaceous schist, chert, and calc-silicate rock occur locally. In Galicia, granitic orthogneiss alternates with amphibolite, forning rather continuous bodies, flattened, stretched, and subsequently folded during the Variscan deformation. Two different igneous associations have been described: (1) a calc-alkaline association formed mainly by tonalites, granodiorites, and high-K granites; and (2) a moderately alkaline association that includes metaluminous alkali-feldspar quartz-syenites and granites, peraluminous alkali-feldspar granites, and peralkaline granites (Rodríguez Aller, 2005). The peralkaline and closely related rocks, which include A-type granitoids, are related to an extensional event that is interpreted to reflect Early (to Middle?) Ordovician rifting (Ribeiro and Floor, 1987; Pin et al., 1992). Their relationship with the calcalkaline magmatism is not completely clear, and some authors correlate both magmatic events with a post-collisional process (Rodríguez Aller, 2005). Granitic and peralkaline orthogneiss yielded Rb-Sr and U-Pb ages of $-490-460 \mathrm{Ma}$ (Van Calsteren et al., 1979; García Garzón et al., 1981; Santos Zalduegui et al., 1995), although there are not enough precise ages to tell whether the two magmatic suites are contemporaneous or not. In any case, the granitic orthogneisses are thought to be older because they are in rude by basic dikes, which are absent in the peralkaline orthogneiss.

Based on previous $\mathrm{Rb}-\mathrm{Sr}$ and $\mathrm{Ar}-\mathrm{Ar}$ isotopic data, subduction is inferred to have started at ca. $370 \mathrm{Ma}$ and ended at ca. $360 \mathrm{Ma}$ (Santos Zalduegui et al., 1995; Rodríguez et al., 2003). After tectonic burial and high-P metamorphism, the P-T evolution of the basal units involved decompression, related to exhumation by underthrusting and tectonic denudation. The samples of this study are from the Agualada and Malpica-Tui basal units (Fig. 3).

\section{ANALYTICAL METHODS}

The analysis of texturally distinct zircon domains, linking their $\mathrm{U}-\mathrm{Th}-\mathrm{Pb}$ ages with specific geologic events, has been used to unravel magmatic and tectonometamorphic evolutions of rocks (e.g., Strachan et al., 1995; Whitehouse et al., 1999; Fernández Suárez et al., 2007). The correct recognition of internal features by cathodoluminescence (CL) allows one to identify layers of zircon that grew during different events and to relate them to distinct processes. The most common problem is to discriminate between late magmatic, metamorphic, or alteration processes that can give rise to the same type of zoning features. The distinction can be delicate, and requires information from various sources including CL images, spot U-Pb analyses, and rare-earth element (REE) composition of the distinct domains. These difficulties can be further reduced combining U-Pb with $\mathrm{Lu}-\mathrm{Hf}$ isotope analyses of discrete zircon domains $\left(\sim 5 \times 10^{-5} \mathrm{~mm}^{3}\right.$; e.g., $40-\mu \mathrm{m}$ Hf spot drilled on top of 30- $\mu \mathrm{m}$ U-Pb spot) using LA-SF-ICP-MS techniques (Gerdes and Zeh, 2006, 2008). In this study, we use this technique to improve constraints on the origin and magmatic and metamorphic evolution of the lower allochthonous units of the NW Iberian Massif.

Zircon was recovere by the usual heavy mineral separation procedure: crushing, sieving, and first concentration of the heavy fraction through a Wilfley table, followed by magnetic and density separation. The final mineral fractions were handpicked under a binocular microscope, mounted in epoxy resin, and polished to get an equatorial section of the grains.

\section{LA-SF-ICP-MS U-Pb Dating}

Uranium and lead isotopes were analyzed using a ThermoScientific Element 2 sector field ICP-MS coupled to a New Wave Research UP-213 ultraviolet laser system at Goethe-University Frankfurt (GUF) following the method described by Gerdes and Zeh (2006, 2008). Data were acquire in timeresolved-peak-jumping-pulse-counting mode over 810 mass scans during 19-second background measurement followed by 30 -second sample ablation. Laser spot-sizes varied from 12 to $30 \mu \mathrm{m}$ with a typical penetration depth of $\sim 15-20 \mu \mathrm{m}$. Signal was tuned for maximum sensitivity for $\mathrm{Pb}$ and $\mathrm{U}$, while keeping oxide production, monitore as ${ }^{254} \mathrm{UO} /{ }^{23} \mathrm{U}$, well below $1 \%$. A teardrop-shaped, low-volume $\left(<2.5 \mathrm{~cm}^{3}\right)$ laser cell with fast response $(<1 \mathrm{~s})$ and low washout time was use (Janoušek et al., 2006; Frei and Gerdes, 2008). With a depth penetration of $\sim 0.6 \mu \mathrm{ms}^{-1}$ and a 0.9 -s integration time
(= 15 mass scans $=1$ ratio), any significant variation of the $\mathrm{Pb} / \mathrm{Pb}$ and $\mathrm{U} / \mathrm{Pb}$ in the $\mu \mathrm{m}$ scale is detectable. Raw data were corrected offline for background signal, common $\mathrm{Pb}$, laser-induced elemental fractionation, instrumental mass discrimination, and time-dependent elemental fractionation of $\mathrm{Pb} / \mathrm{U}$ using an in-house Microsoft Excel ${ }^{\bullet}$ spreadsheet program (Gerdes and Zeh, 2006, 2008). A common- $\mathrm{Pb}$ correction based on the interference- and background-corrected ${ }^{204} \mathrm{~Pb}$ signal and a model $\mathrm{Pb}$ composition (Stacey and Kramers, 1975) was carried out, where necessary. The necessity of the correction was judge on whether the corrected ${ }^{207} \mathrm{~Pb} /{ }^{206} \mathrm{~Pb}$ lay outside of the internal errors of the measured ratios. This was the case for less than $10 \%$ of the analyses. Uncertainties related to the common $\mathrm{Pb}$ correction, e.g., $4 \%$ uncertainty on the assumed ${ }^{20} \mathrm{~Pb} /{ }^{20} \mathrm{~Pb}$ composition, were quadratically added to final uncertainty. The interference of ${ }^{24} \mathrm{Hg}$ (mean $=129 \pm 18$ counts per second [cps]) on the mass 204 was estimated using a ${ }^{20} \mathrm{Hg} /{ }^{2} \mathrm{Hg}$ ratio of 0.2299 and the measured ${ }^{2{ }_{2}} \mathrm{Hg}$. Laser-induced elemental fractionation and instrumental mass discrimination were corrected by normalization to the reference zircon GJ-1 (Jackson et al., 2004). Prior to this normalization, the drift in interelemental fractionation $(\mathrm{Pb} / \mathrm{U})$ during 30-s sample ablation was corrected for the individual analysis. The correction was done by applying a linear regression through all measure ratios, excluding the outliers ( \pm 2 standard deviation [2 SD]), and using the intercept with the $y$-axis as the initial ratio. The total offset of the measured driftcorrecte ${ }^{206} \mathrm{~Pb} / 238 \mathrm{U}$ ratio from the "true" isotope dilution-thermal ionization mass spectrometry (ID-TIMS) value of the analyzed GJ-1 grain was typically $\sim 3 \%-9 \%$. Reported uncertainties (2 sigma [2б]) of ${ }^{206} \mathrm{~Pb} /{ }^{238} \mathrm{U}$ were propagated by quadratic addition of the external reproducibility ( 2 SD) obtained from the standard zircon GJ-1 ( $n=12 ; 2$ SD $~ 1.3 \%)$ during the analyti$\mathrm{cal}$ session and the within-run precision of each analysis (2 standard error [SE]). The external reproducibility of the ${ }^{207} \mathrm{~Pb} /{ }^{206} \mathrm{~Pb}$ of $\mathrm{GJ}-1$ was $0.9 \%$ (2 SD). However, because ${ }^{20} \mathrm{~Pb} /{ }^{206} \mathrm{~Pb}$ uncertainty during LA-SF-ICP-MS analysis is directly dependent on ${ }^{207} \mathrm{~Pb}$ signal strength, uncertainties were propagated following Gerdes and Zeh (2008). The ${ }^{235} \mathrm{U}$ was calculated from the ${ }^{238} \mathrm{U}$ divide by 137.88 and the ${ }^{207} \mathrm{~Pb} /{ }^{235} \mathrm{U}$ uncertainty by quadratic addition of the ${ }^{206} \mathrm{~Pb} /{ }^{238} \mathrm{U}$ and the ${ }^{201} \mathrm{~Pb} /{ }^{206} \mathrm{~Pb}$ uncertainty

\section{LA-MC-ICP-MS Lu-Hf Isotope Analyses}

Hafnium isotope measurements were performed with ThermoScientific Neptune multicollector ICP-MS at GUF coupled to the same 
Figure 3. Geologic map of the NW corner of Galicia showing the different orthogneisses of the basal units and the location of the selected samples.

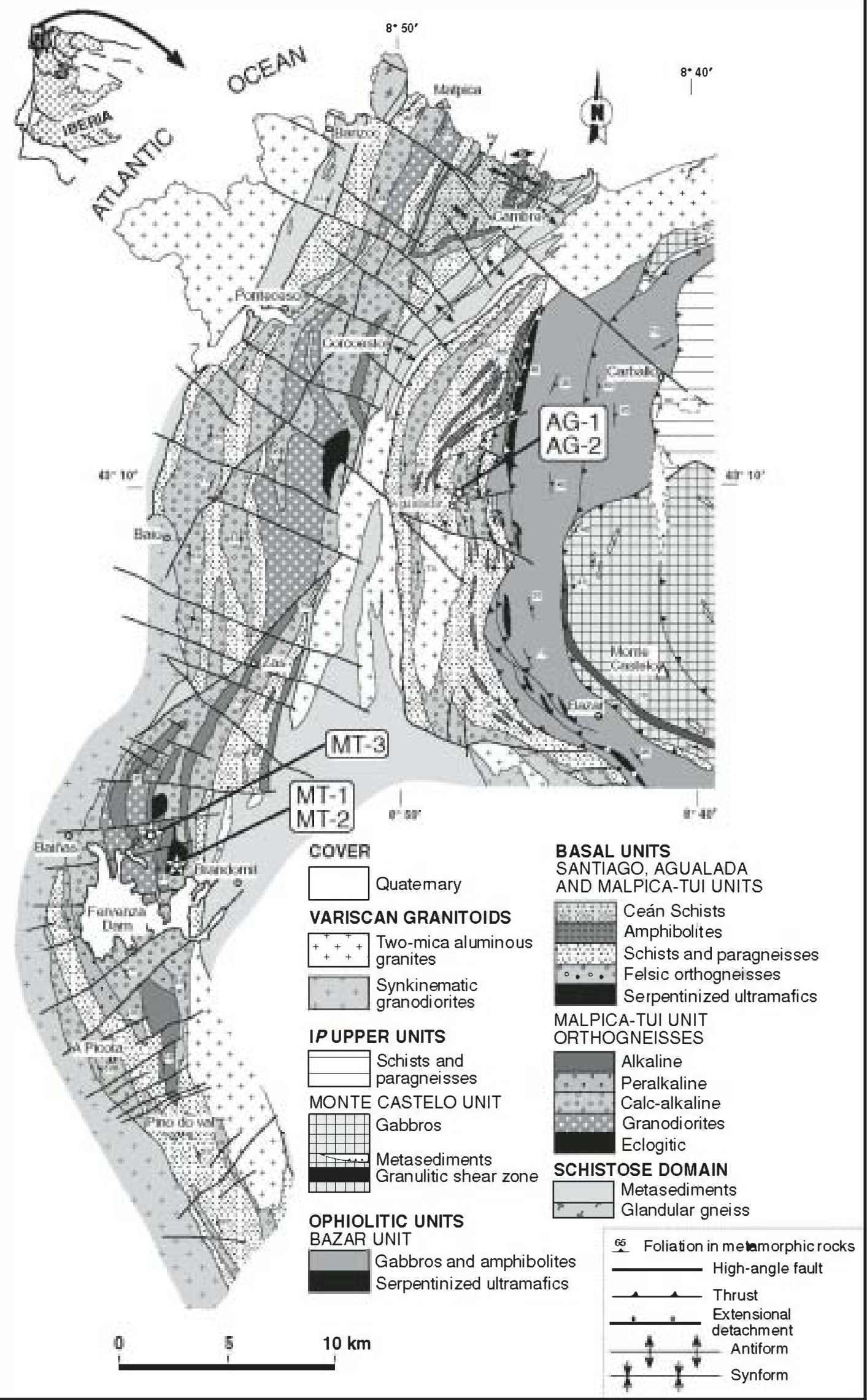


laser system and laser cell as described above. Data were collected in static mode $\left({ }^{172} \mathrm{Yb},{ }^{173} \mathrm{Yb}\right.$, ${ }^{175} \mathrm{Lu},{ }^{176} \mathrm{Hf}-\mathrm{Yb}-\mathrm{Lu},{ }^{177} \mathrm{Hf},{ }^{178} \mathrm{Hf},{ }^{179} \mathrm{Hf}$, and ${ }^{180} \mathrm{Hf}$ ) during 58 seconds of laser ablation. When possible, the "Lu-Hf laser spot" of $40 \mu \mathrm{m}$ diameter was drilled "on top" of the $30 \mu \mathrm{m}$ "U-Pb laser spot." Nitrogen ( 0.005 L/min) was introduced via a Cetac Aridus into the Ar sample carrier gas to enhance sensitivity $(\sim 10 \%-20 \%)$ and to reduce oxide formation. The use of the Aridus system allowed bracketing of laser ablation analyses with solution mode analyses. Analytical protocols were the same for laser ablation and solution mode analyses. The isotopes ${ }^{172} \mathrm{Yb}$, ${ }^{173} \mathrm{Yb}$, and ${ }^{175} \mathrm{Lu}$ were simultaneously monitored during each analysis step to allow for correction of isobaric interferences of $\mathrm{Lu}$ and $\mathrm{Yb}$ isotopes on mass 176 . The ${ }^{176} \mathrm{Lu}$ and ${ }^{176} \mathrm{Yb}$ were calculated using ${ }^{176} \mathrm{Lu} /{ }^{175} \mathrm{Lu}$ of 0.02658 and ${ }^{176} \mathrm{Yb} /{ }^{173} \mathrm{Yb}$ of 0.795015 (both GUF in-house values). For a more detailed discussion, see Gerdes andZeh (2008).

\section{SIMS U-Pb Dating}

The U-Pb dating was performed using a CAMECA IMS1270 ion microprobe at the NORDSIM facility, Swedish Museum of Natural History, Stockholm. Analyses and datareduction procedures follow those outlined by Whitehouse et al. (1999) and references therein. In brief, an $\sim 5 \mathrm{nA} \mathrm{O}_{2}$-primary beam was used in aperture illumination mode to sample nominal $\sim 25 \mu \mathrm{m}$ elliptical areas. The mass spectrometer was operated in single-collection mode at a mass resolution of $\sim 5000$, with secondary ions detected using an ion-counting electron multiplier. $\mathrm{Pb} / \mathrm{U}$ ratios, calibrated against the 91500 standard zircon, include an error component propagated from the standard analyses in a particular session, while $\mathrm{Pb}$-isotope ratio errors are based on counting statistics or observed errors. Correction for common lead uses measured ${ }^{2} \mathrm{~Pb}$ and assumes a present-day composition from the Stacey and Kramers (1975) model. All data reduction was carried out using the routines of Isoplot (Ludwig, 2003).

\section{RESULTS AND DISCUSSION OF ZIRCON MORPHOLOGY, CATHODOLUMINESCENCE IMAGES, AND ISOTOPE ANALYSES}

U-Pb SIMS analyses were performed on zircons from three samples of mafic and intermediate eclogitic rocks, and combined $\mathrm{U}-\mathrm{Pb}$ and Lu-Hf in situ LA-ICP-MS analyses were performed on zircons from two samples of felsic eclogitic orthogneiss.

Figure 4. Petrographic appearance of the analyzed samples. (A) Felsic orthogneiss of the Agualada Unit (AG-1) with blastomylonitic texture, abundant recrystallized quartz ribbons, and K-feldspar, plagioclase, and garnet porphyroclasts. (B and G) Retrogressed eclogite of the Agualada Unit (AG-2), which is enclosed in the felsic gneisses. The eclogitic assemblage is formed by garnet, omphacite, rutile, and quartz. Post-eclogitic phases include hornblende, plagioclase, and epidote. Some samples show a primary honeycomb texture formed by omphacite surrounded by garnet (G), partially retrograded to amphibolite facies. (C) Coronitic metagranite (MT-3) from the Malpica-Tui Unit showing garnet overgrowths surrounding igneous biotite and plagioclase partially transformed in albite, epidote/clinozoisite and phengite. (D-F) Eclogitic rocks from the Malpica-Tui Unit (MT-1 and MT-2). The eclogitic association includes garnet, omphacite, rutile, clinozoisite, and phengite (MT-2; D), and occasionally a later generation of poikiloblastic sodic amphiboles can be observed (E). The eclogitic gneisses (MT-1; F) have a similar mineral assemblage but with a high proportion of quartz and abundant kyanite.

\section{Agualada Unit}

In the northwest of the Ordenes Complex, around Agualada (Fig. 3), a migmatitic basal unit sits on top of another basal unit of lower metamorphic grade along a thrust fault. P-T estimates on eclogitic lenses yield temperatures of $720^{\circ} \mathrm{C}$ and a minimum pressure of $1.5 \mathrm{GPa}$ (Arenas et al., 1997). Discontinuous lenses of ul tramafic rock at the bounding fault and in a narrow shear zone inside the high-grade unit point to the imbricate character of thrusting and indicate that mantle is carrie in the thrust sheets.

The Agualada Unit is a small $(2.5 \times 3 \mathrm{~km}$ of outcrop surface), imbricated tectonic slice between the Santiago Unit and the ophiolite (Fig. 3). It is the only basal unit that shows evidence of incipient partial melting, and consists of migmatitic paragneiss and an elongate body of granitic orthogneiss. The paragneiss and orthogneiss bodies contain stretched and boudinaged eclogite that are interpreted as metamorphosed mafic dikes. We separated zircons from the granitic orthogneiss and the eclogitic boudins (Fig. 4).

\section{Felsic Gneiss (Sample AG-1)}

The main mineralogy is quartz, K-feldspar, plagioclase, biotite, muscovite, and rare gamet and accessory minerals, arranged in a fine- to medium-grained blastomylonitic texture with abundant ribbons of recrystallized quartz and feldspar surrounding porphyroclasts (Fig. 4A). These mylonites have a strong stretching lineation, and only in rare weakly deforme areas is a slightly porphyritic igneous texture visible Geochemically, the gneisses are calc-alkaline granitoids with volcanic arc affinities (Fig. 6E) They contain numerous zircons with variable shape and size, usually idiomorphic and some more than $300 \mu \mathrm{m}$ long. Their color varies from clear and colorless to brownish-gray and ahnost opaque. Despite the great variety, the cathodo- luminescence (CL) study shows that most of them have a similar core-rim internal texture. The cores usually exhibit concentric oscillatory zoning, with regular narrow zones, typically for zircon grains crystallized in granitic magmas (Hoskin, 2000). Cores are bound either by idiomorphic surfaces or by irregular shapes indicating variable degrees of resorption. These domains, interpreted as magmatic, are ubiquitously overgrown by a dark homogeneous rim that thickens the crystals in variable amounts, reaching a maximum thickness around $60 \mu \mathrm{m}$ (Fig. 5). Commonly, the ransition between the growth-zoned domains and the homogeneous rims is gradual, leaving an intervening area where the zoning is progressively blurred and darkened (Figs. 5A and 5E-5H). These relicts of primary textures within areas of recrystallization are known as "ghost" textures and can be responsible for "mixed" isotopic ages between growth-zoned and fully recrystallized areas (Corfu et al., 2003a). Conversely, in some cases, the rim domains cut discordantly across the growth-zoned domains (Fig. 5C). When the intemal areas of zircons show resorption, the newly grown rims surround the cores leaving sharper contacts, pene rating and sealing the earlier lobes and gulfs generated during this process (Figs. 5B and 5D). Clear xenocrystic cores were only observed in two grains (Figs. 5I and 5M). All of these textures are consistent with magmatic growth of the cores in a process involving resorption, and probably some late magmatic recrystallization, followed by later growth of metamorphic zircon, at least in part in solid state, as the "ghost" textures suggest (Hoskin and Black, 2000). This textural interpretation is also in agreement with the contrasting $\mathrm{Th} / \mathrm{U}$ ratios found in both domains. Several studies have demonstrated that low $\mathrm{Tb} / \mathrm{U}$ ratios are characteristic of (although not exclusively) metamorphic zircons (e.g., Rubatto, 2002; 

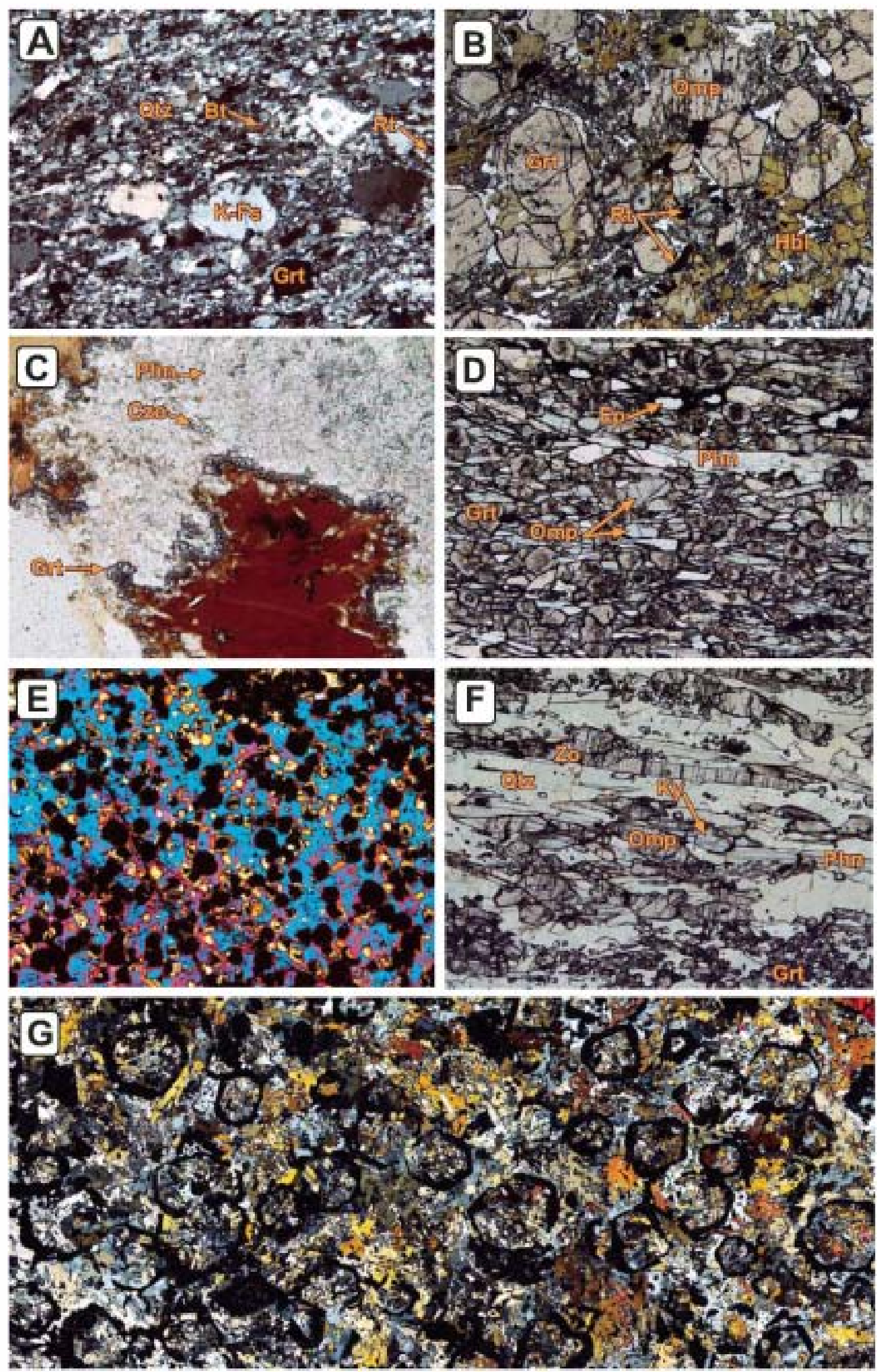


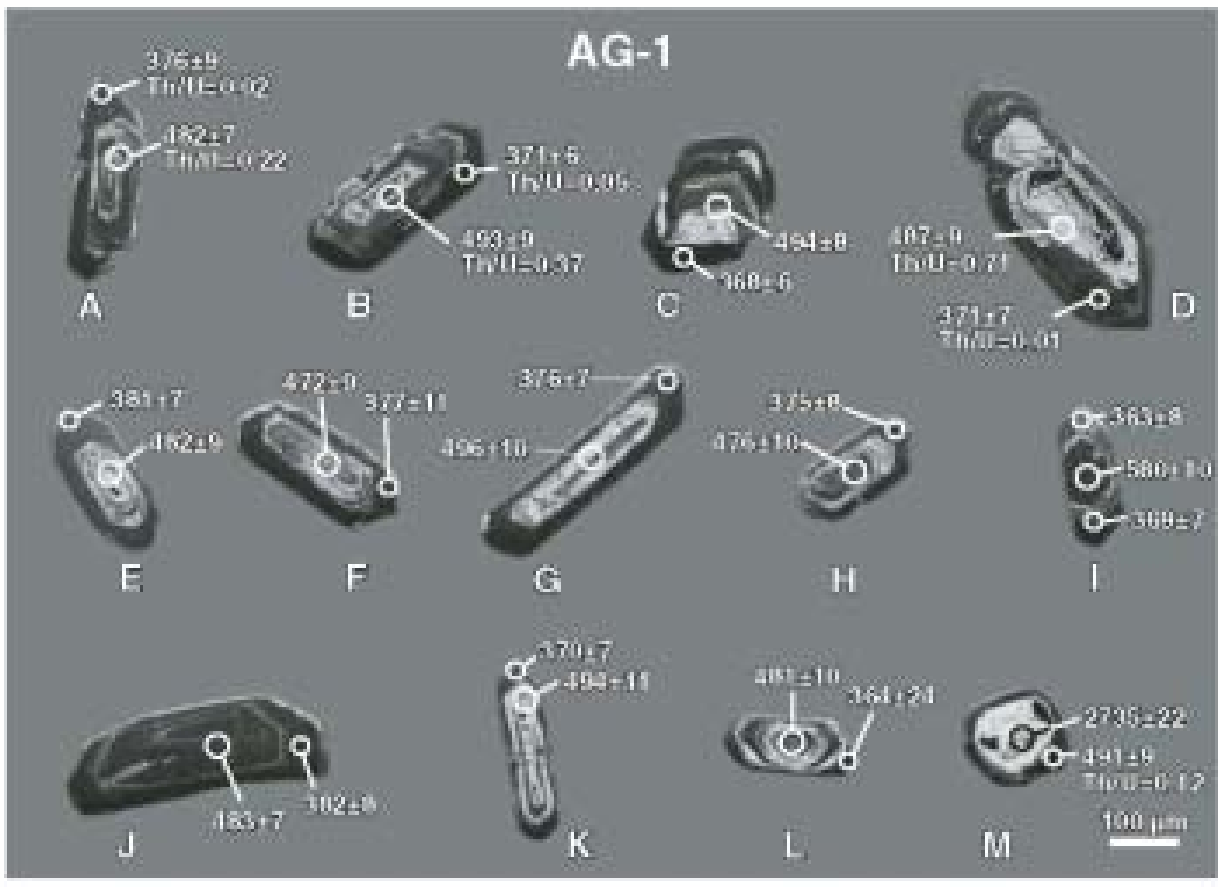

Figure 5. Cathodoluminescence images of zircons from the Agualada felsic gneisses showing their typical core-rim internal texture. The laser spots are marked by open circles labeled with the ${ }^{206} \mathrm{~Pb} /{ }^{238} \mathrm{U}$ ages and corresponding $2 \sigma$ errors (except for the Archean core, which is $a^{207} \mathrm{~Pb} /{ }^{206} \mathrm{~Pb}$ age) and some examples with representative $\mathrm{Th} / \mathrm{U}$ ratios.

Harley et al., 2007). In this case, the rims show systematically lower $\mathrm{Tb} / \mathrm{U}$ ratios than the cores, ranging from less than 0.01 to 0.17 in the rims and 0.15 to 0.4 in the cores (see GSA Data Repository Tables DR1 and DR2 ${ }^{1}$ ). However, in some cases the core-rim textures may have different origins, and even very similar rims can be magmatic, growing over xenocrysts (e.g., Fig. 5M).

Uranium-lead analyses on the cores were performed using a laser beam of $30 \mu \mathrm{m}$, whereas for the rims we use 20,16 , or $12 \mu \mathrm{m}$ spots, depending on thickness and U content. Seventy spots of magmatic cores from 68 grains were analyzed. The results reveal different ages but with a peak clustering at $493 \mathrm{Ma}$ (Figs. 6A and $6 \mathrm{~B})$. Twenty analyses yield concordant and equivalent results corresponding to a concordia age of $493 \pm 2 \mathrm{Ma}$ (Figs. 6A and 6B), which we consider as best age estimation for magma emplacement. A smaller group of younger ages, between 420 and 480 (Fig. 6A), probably reflect lead loss due to a later metamorphic event or alteration process. We can, however, not rule out that a minor age peak around $460 \mathrm{Ma}$ (Fig. 6A) represents a geologic event, such as

${ }^{1}$ GSA Data Repøsitøry item 2009135, Data tables with the U-Pb and $\mathrm{Lu}-\mathrm{Hf}$ analytical results, is available at http://www.ge•søciety.•rg/pubs/ft2009.htm -r by request t•editing @geosøciety.・rg. a new magmatic pulse. It is interesting to note that inherited zircon cores are rare, suggesting dissolution of most preexisting zircon due to $\mathrm{Zr}$-undersaturated conditions in the melt, or magma generation from a juvenile source with limited crustal contamination. Seven inherite cores yielded Precambrian ages between 550 and $600 \mathrm{Ma}$ (Fig. 5I), and one gave an Archean ${ }^{207} \mathrm{~Pb} / 2{ }^{\circ 6} \mathrm{~Pb}$ age of $2735 \mathrm{Ma}$ (Fig. 5M).

Thirty spots on the zircon overgrowth rims yielded a wide age span, ranging from 331 to $397 \mathrm{Ma}$, with maxima around $372 \mathrm{Ma}$, indicating that they grew more than $100 \mathrm{Ma}$ later than the cores. Thirteen yield equivalent and concordant results corresponding to a concordia age of $372 \pm 3$ (Figs. $6 \mathrm{~A}$ and $6 \mathrm{C}$ ), which we interpret as age of zircon overgrowth related to high-pressure metamorphism. A few analyses older than $380 \mathrm{Ma}$ are more discordant (90\%-106\% concordant), and likely represent mixtures between magmatic and metamorphic ages, or incomplete recrystallized zircon domains as supported by the Hf isotope data (next section). The plots of Figure $6 \mathbf{1}$ also show a minor age peak around $350 \mathrm{Ma}$. The most straightforward interpretation would be to consider them as a consequence of continuous or episodic lead loss due to a later process. However, as we will discuss below, this age could be geologically meaningful.
The Lu-Hf isotope analyses have been performed on 28 magmatic and four inherited cores, as well as on 19 overgrowth rims (Fig. 7). The cores with ${ }^{206} \mathrm{~Pb} /{ }^{38} \mathrm{U}$ ages of $450-500 \mathrm{Ma}$ (Group A in Fig. 7A) show a uniform composition with ${ }^{176} \mathrm{Hf} /{ }^{177} \mathrm{Hf}(\mathrm{t})$ of $0.282346 \pm 0.000028$ (2 SD), which is close to the reproducibility of the applied method. In contrast, the ${ }^{176} \mathrm{Hf} /{ }^{177} \mathrm{Hf}(\mathrm{t})$ of the overgrowth rims varies strongly, from 0.2824 to 0.2826 (Fig. 7A). This is in line with the previous interpretation, suggesting that the rim domains are metamorphic overgrowths and do not represent post-magmatic growth alteration. The latter can be the result of different processes, i.e., metamictization followed by diffusion and/or fluid-driven, dissolutionreprecipitation or diffusion-reaction processes that cause partial or total Pb-loss (e.g., Pidgeon, 1992; Mezger and Krogstad, 1997; Vavra and Schaltegger, 1999; Geisler et al., 2007; Gerdes and Zeh, 2008). However, as has been shown by Gerdes and Zeh (2008), such domains would maintain an Hf isotopic composition analytically indistinguishable from that of the initial, pristine zircon. In contrast, most overgrowth rims with a ${ }^{206} \mathrm{~Pb} /{ }^{23} \mathrm{U}$ age of ca. $370 \mathrm{Ma}$ (Group $B$ in Fig. 7A) analyze here have ${ }^{176} \mathrm{Hf} /{ }^{177} \mathrm{Hf}(\mathrm{t})$ ratios that are higher than the cores. This is typical for newly formed zircon, which incorporates additional radiogenic ${ }^{176} \mathrm{Hf}$ formed by ${ }^{176} \mathrm{Lu}$ decay in the rock's matrix between successive zircon growth events. Only negligible amounts of such ${ }^{176} \mathrm{Hf}$ are ever incorporated into zircon domains affected by post-growth alteration (Gerdes and Zeh, 2008).

Some analyses of the overgrowth rims appear to be mixtures of both magnatic and metamorphic zircon with ransitional ${ }^{176} \mathrm{Hf} /{ }^{177} \mathrm{Hf}(\mathrm{t})$ (group $\mathrm{C}$; around 0.2824 ) and ${ }^{20}{ }^{0} \mathrm{~Pb} /{ }^{38} \mathrm{U}$ ages, indicating either analytical mixing of core and rim domains or partial resetting of the U-Pb system and incomplete exchange of radiogenic $\mathrm{Hf}$ with the matrix. Partial reequilibration would be consistent with the persistence of "ghost" textures between the magmatic zircons and the complete recrystallize rims. The large variation of ${ }^{176} \mathrm{Hf} /{ }^{177} \mathrm{Hf}(\mathrm{t})(0.28244-0.28260)$ and the ${ }^{176} \mathrm{Lu} /{ }^{177} \mathrm{Hf}$ shown by the overgrowth rims indicate incomplete equilibration of the $\mathrm{Lu}-\mathrm{Hf}$ system in the rock during high-P metamorphism, perhaps due to multiple phases of zircon crystallization and relatively low temperatures during metamorphism. The slight decrease of the ${ }^{176} \mathrm{Lu} /{ }^{177} \mathrm{Hf}$ ratio in metamorphic relative to magmatic zircon (Fig. 7C) is consistent with crystallization of a small amount of garnet during metamorphism in the felsic gneiss, as garnet has a strong affinity for the heavy rare-earth elements (HREEs) compared to zircon (e.g., metamorphic zircons in eclogite are strongly 

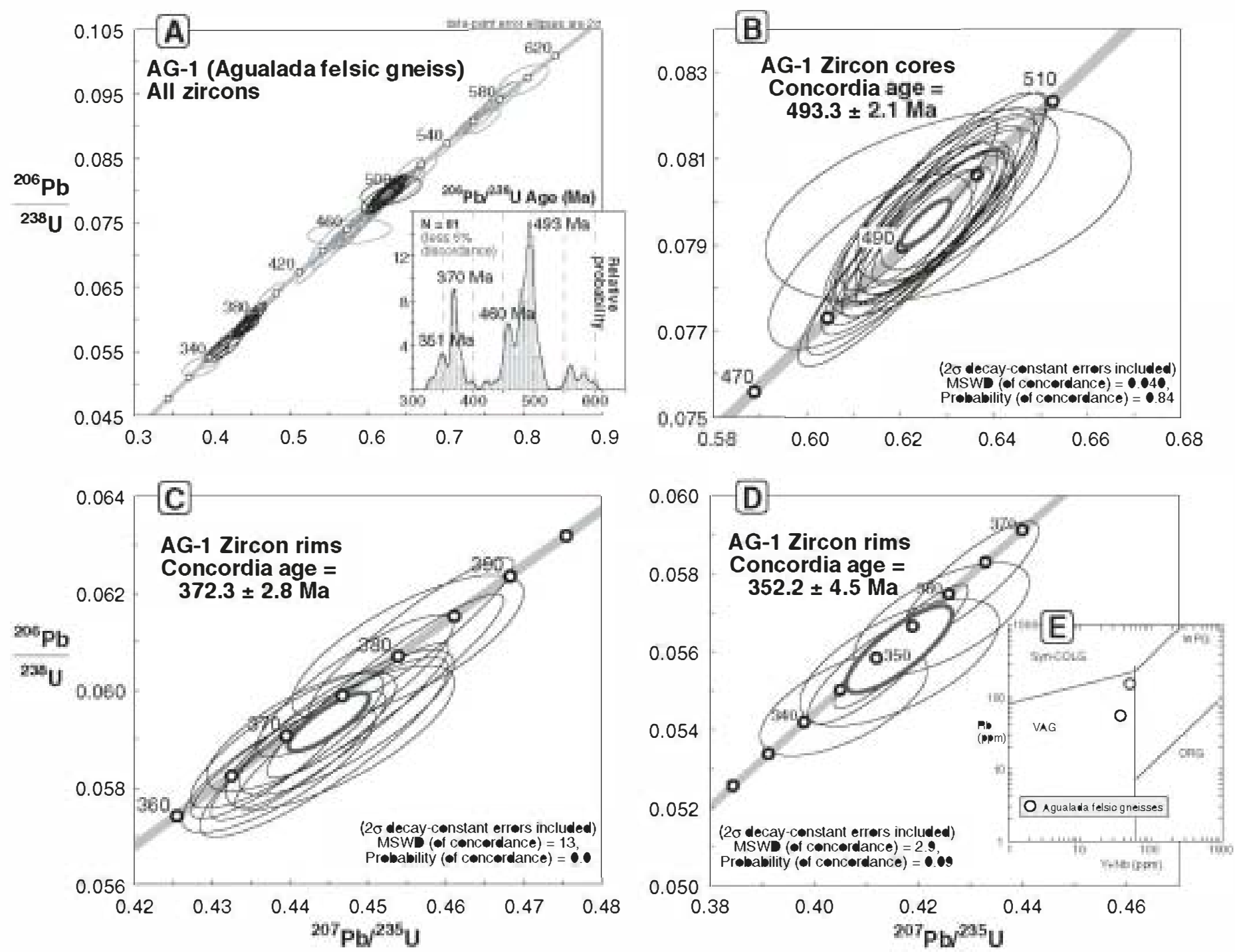

Figure 6. U-Pb concordia diagrams and probability plot for Agualada felsic gneiss (AG-1). (A) Plots show all spots analyzed that are less than $10 \%$ discordant (excluding paleo-Proterozoic inheritances). Error ellipses in black represent the analyses used for the calculation of concordia ages shown in the diagrams (B-D). The inset is the relative probability plot for the less than 5\% discordant analyses. (B) Concordant analyses of zircon cores and the calculated concordia age, interpreted as the age of magmatism. (C) Plot of data for zircon rims and the calculated concordia age. (D) Plot of the younger data for zircon rims and the calculated concordia age. Error ellipses are 20. (E) Tectonic discrimination diagram for two samples of the Agualada felsic gneisses. Abbreviation: MSWD-mean square of weighted deviates.

depleted in Lu). Perographic observations confim that the felsic gneisses have only accessory amounts of garnet. The group with isotopically mixed ${ }^{176} \mathrm{Hf} /{ }^{177} \mathrm{Hf}(\mathrm{t})$ ratios $(\mathrm{C})$ interestingly has higher Lu/Hf than the 350-380 Ma zircon domains (Fig. 7C), which suggests an evolution from the magmatic domains to the completely recrystallize or newly formed metamorphic domains involving an initial weak enrichment in $\mathrm{Lu} / \mathrm{Hf}$ with limited exchange of radiogenic Hf and partial resetting of the U-Pb system, and subsequently a complete recrystallization with a moderate decrease of the Lu/Hf ratio and an extensive exchange of radiogenic Hf with the rock matrix. This evolution suggests that the initial stages of metamorphism probably favored partial lead loss and alteration of zircon rims accompanie by HREE enrichment (altere zircon domains typically get enriched in HREE; e.g., Gerdes and Zeh, 2008) before the activation of the main, new zircon-forming reactions, which permitted complete recrystallization, radiogenic Hf exchange, and lowering of the $\mathrm{Lu} / \mathrm{Hf}$ ratio.

\section{Eclogite (Sample AG-2)}

Boudins of strongly sheared and stretched mafic dikes are common within the orthogneiss and the mignatitic metasediment. The central parts of the boudins locally show an eclogitic foliation formed by omphacite, rutile, and garnet (Figs. $4 \mathrm{~B}$ and $4 \mathrm{G}$ ), which is runcated by an external, amphibolite facies foliation (the regional foliation). These eclogites have a complex metamorphic history; their textural evolution involves two generations of omphacite and garnet. The high-pressure part of their P-T path is characterize by cooling and subsequent heating, reaching a maximum of $720^{\circ} \mathrm{C}$ and more than $15 \mathrm{kbar}$ (Arenas et al., 1997). We sampled the central part of two of these boudins with the best preserved high-P minerals. They contain very few zircons, commonly smaller than 

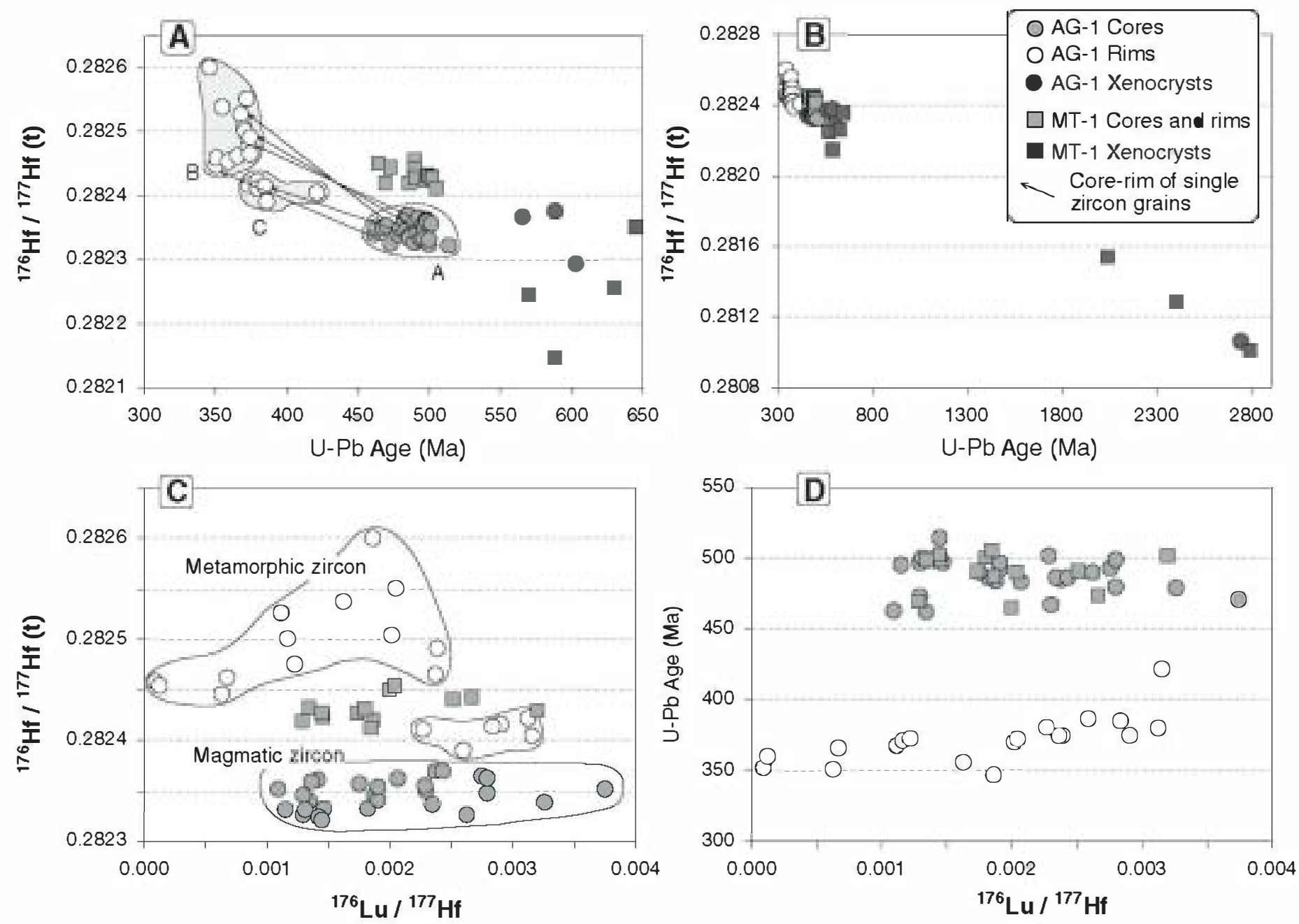

Figure 7. Plots of the initial ${ }^{176} \mathrm{Hf} /{ }^{177} \mathrm{Hf}$ ratio versus U-Pb age (A and B); initial ${ }^{176} \mathrm{Hf} /{ }^{177} \mathrm{Hf}$ versus ${ }^{176} \mathrm{Lu} /{ }^{177} \mathrm{Hf}(\mathrm{C})$; and $\mathrm{U}-\mathrm{Pb}$ age versus ${ }^{176} \mathrm{Lu} /{ }^{177} \mathrm{Hf}$ (D). (A) Metamorphic zircons of sample AG-1 (group B) have higher ${ }^{176} \mathrm{Hf} /{ }^{177} \mathrm{Hf}$ than magmatic zircon domains (group A), and partially recrystallized rims have an intermediate composition (group C). Arrows connect some of the core-rim analyses of individual zircon grains. The MT-1 zircons do not present overgrowth rims and have a slightly more radiogenic ("juvenile") Hf isotope composition than AG-1 grains. (B) The same plot including all xenocrystic zircon grains. (C and D) The ${ }^{176} \mathrm{Lu} /{ }^{77} \mathrm{Hf}$ ratios of the metamorphic zircon domains are only slightly lower than those of the magmatic zircon, suggesting a limited control by garnet during metamorphism.

$60 \mu \mathrm{m}$; only 36 grains were recovered from the two samples. The zircon grains are rounded and alotriomorphic, but some are subidiomorphic, equidimensional, and multifaceted. Under CL, they show an internal texture that varies from ahnost homogeneous to irregularly zoned with patches showing different luminescence, and less commonly with sector and fir-ree zoning (Figs. 8J-80). The small and rounded shape and the irregular zoning are typical of metamorphic zircons, and we did not find any zircon with regular growth zoning. Thirty-six SIMS U-Pb analyses were performed, and a subset of the 20 most concordant analyses yields a concordia age of $351 \pm 2 \mathrm{Ma}$ (Fig. 9A, Table DR3 [see footnote 1]). The low $\mathrm{Th} / \mathrm{U}$ ratio of the zircons, with a mean value of 0.018 , is consistent with a metamorphic origin. This age opens an interesting question, because we have to determine whether it represents or is somehow linked to the eclogitic metamorphic event or if it records a later event. An older age for the high-P metamorphism is supported by Ar-Ar ages obtained in eclogite and other high-P rocks from equivalent basal units in Galicia and the Amnorican Massif that peak at 360-370 Ma (Rodríguez et al., 2003; Bosse et al., 2005; Fig. 1). The Ar-Ar ages are in agreement with the tightly constrained age of the metamorphic overgrowths of the orthogneiss that encloses the eclogite boudins $(372 \pm 3 \mathrm{Ma})$. Therefore, we think that the zircons from the eclogite boudins grew during a later event, probably the same event that gave rise to the partial melting of the mignatitic metasediments of the Agualada Unit. The release of fluids during the incipient melting, mainly coming from the metasediments, may have induced minimum melting of the mafic rocks that catalyzed new zirconforming metamorphic reactions.

The U-Pb age of metamorphic zircons from eclogite is commonly interpreted as a good approximation of the age of the eclogiticmetamorphism (e.g., Rubatto et al., 1999; Corfu et al., 2003b; Baldwin et al., 2004), which is probably rue in most cases, but not necessarily always. The interpretation of $\mathrm{U}-\mathrm{Pb}$ ages in eclogites as the time of peak of high-P metamorphism should be taken with caution, because in some cases (as demonstrated here) zircon may represent post-eclogitic growth, even in low- to 
medium-temperature terranes. Consequently, independent evidence is require to ensure that metamorphic zircon ages from eclogite reflect the high-P peak

\section{Paragneiss}

Another line of evidence that supports the interpretation of the zircon ages of the eclogite as related to a post-peak metamorphic thermal event comes from the paragneisses. Their incipient partial melting, simultaneous with the development of the regional foliation, is related to decompression and took place under amphibolite-facies conditions (Abati, 2002). This regional foliation locally penetrates the rims of the included mafic lenses producing intense amphibolitization and transposition of the previous syneclogitic fabric. Abati and Dunning (2002) date monazites and rutiles from the paragneiss by TIMS at $346 \pm 2 \mathrm{Ma}$ and $341 \pm 3 \mathrm{Ma}$, respectively. These ages are interpreted as dating migmatization (monazite) and subsequent rapid cooling (rutile).

\section{Malpica-Tui Unit}

The Malpica-Tui Unit is the westemmost exposure of the basal units in the NW Iberian Massif, and the maximum pressures of metamorphism are reached here. Pressure estimates in different lithologies gave a peak at 18-25 kbar (Gi1 Ibarguchi, 1995; Rodríguez et al., 2003; López Carmona, 2007), indicating burial to depths in excess of $70 \mathrm{~km}$. Mafic and intermediate eclogitic rocks are among the most characteristic high-P lithologies. They appear, like the Agualada eclogite, as meterto decameter-sized enclaves in other igneous and metasedimentary rocks, especially felsic gneisses, but also as larger and discontinuous massifs that can be more than $1 \mathrm{~km}$ long. We sampled both types of eclogite from one of these massifs (Fig. 3), and another characteristic high-P rock, a corona-texture, jacleitebearing metagranite (Gi1 Ibargucbi, 1995).

\section{Eclogite and Eclogitic Gneiss (Samples MT-1 and MT-2)}

The geochemistry of the intermediate and mafic high-P rocks indicates that they derive from a calc-alkaline igneous suite (Rodríguez Aller, 2005). The eclogite s.s. (sensu stricto) (sample MT-2) is commonly fine-grained and nematoblastic. The oldest metamorphic mineral assemblage consists of garnet, omphacite, rutile, zoisite, white mica, and rarely kyanite (Figs. 4D and 4F). Occasionally, glaucophane, barroisite, and other amphiboles grow after omphacite and gamet (Fig. 4E). The effects of a final retrogressive, amphibolite to greenschist facies meta-

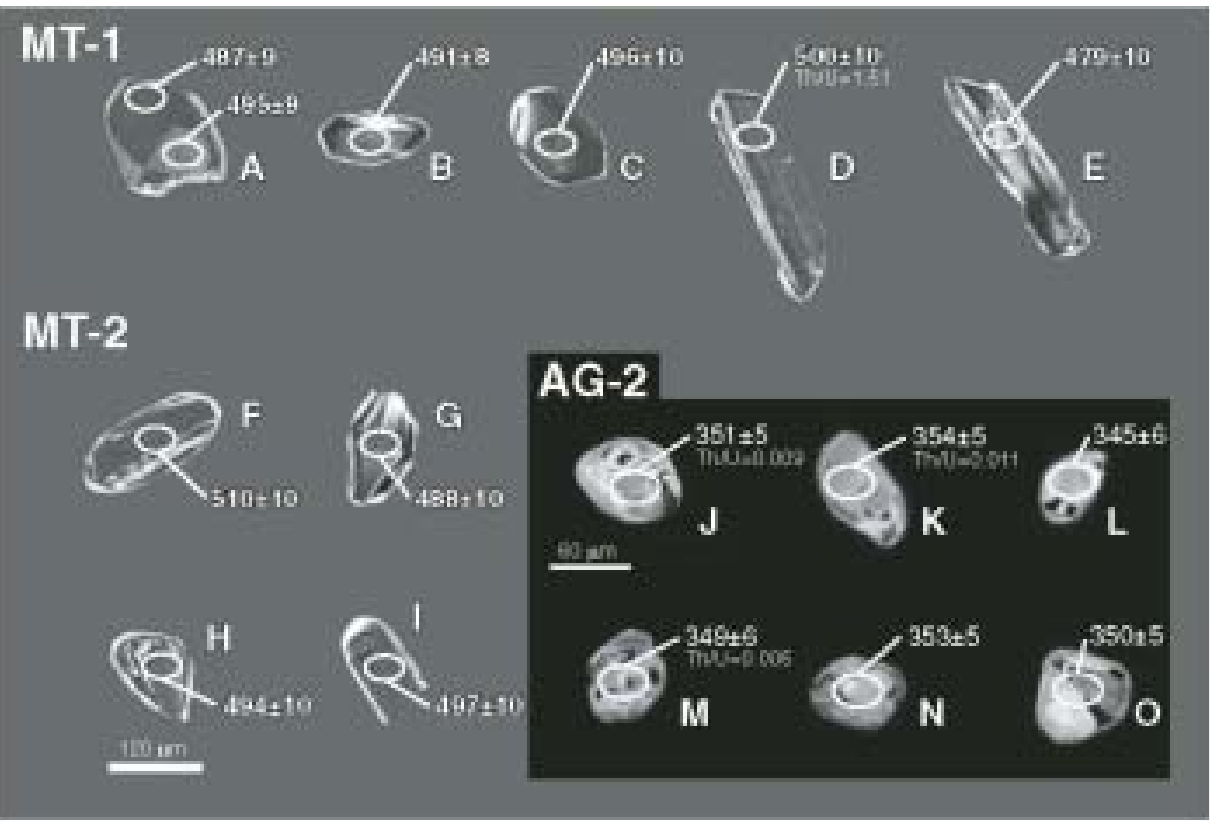

Figure 8. Cathodoluminescence images of zircons from eclogitic rocks: Agualada eclogite (AG-2); Malpica-Tui eclogitic gneisses (MT-1); and Malpica-Tui eclogite (MT-2). The secondary ion mass spectrometry (SIMS) spots are marked by open ellipses labeled with the ${ }^{206} \mathrm{~Pb} /{ }^{238} \mathrm{U}$ ages and corresponding $2 \sigma$ errors. Rounded zircon grains from AG-2 show sector and patch zoning and very low $\mathrm{Th} / \mathrm{U}$ ratios typical for a metamorphic origin. No relict zircon domains of obvious igneous origin have been identified in this sample. Zircon grains from MT-1 and MT-2 show oscillatory zoning typical of igneous zircon crystallized in less evolved magmas. Contrary to zircon crystals from AG-1, they did not develop metamorphic overgrowth rims during the high-pressure metamorphism.

morphic event are widespread. The eclogitic gneisses are intermediate, metatonalitic rocks (sample MT-1). The name gneisses was given mainly on textural grounds (Rodríguez Aller, 2005), because these rocks commonly show a gneissic texture formed by light layers of quartz and phengite alternating with dark layers rich in omphacite, garnet, rutile, zoisite, and kyanite (Fig. 4F). Both types of eclogitic rocks are spatially associated in the field, and their chemical composition is similar, suggesting that they may be products of the same magmatic evolution. We recovered zircon grains from two samples of the less retrograded eclogite and eclogitic gneisses. The zircons are mostly idiomorphic to subidiomorphic, variably shaped but with a tendency toward pyramidal and multifaceted shapes rather than prismatic. Under CL, they show different zoning patterns. In the eclogite (MT-2), the most common patterns are sector zoning and the development of broad bands parallel to the crystal faces, although homogeneous, patchy, and convoluted zoning also exists (Fig. 8). Rarely, intricate textures revealing different stages of magmatic growth can be found. The zircons from the eclogitic gneiss (MT-1) are similar, but with more abundant prismatic shapes and growth zoning with narrower bands. These features are common in zircons formed in less evolved magmas (Hoskin, 2000). Despite the complete recrystallization, textural reconstruction, and deformation (with a peak around $610^{\circ} \mathrm{C}$; Rodríguez et al., 2003) of the original igneous rock, there are no metamorphic rims, except very thin and bright luminescent ones, which are too thin to be analyzed. Twenty-five spots on each sample were analyzed by SIMS at the Natural History Museum of Stockholm.

\section{Eclogitic Gneisses (Sample MT-1)}

A group of 19 equivalent and concordant analyses yield a concordia age of $494 \pm 3 \mathrm{Ma}$ (Fig. 9B).

\section{Eclogite (Sample MT-2)}

The most concordant isotopic data of oscillatory-zoned cores from 23 grains yield an age of $498 \pm 6 \mathrm{Ma}$ (Fig. 9C). Two attempts to date the thin, bright, luminescent rims gave similar "magmatic" ages.

Taking into account the better quality of the data obtained for the eclogitic gneisses (MT-1), their more concordant character, and that the age overlaps within error with the eclogite sample 

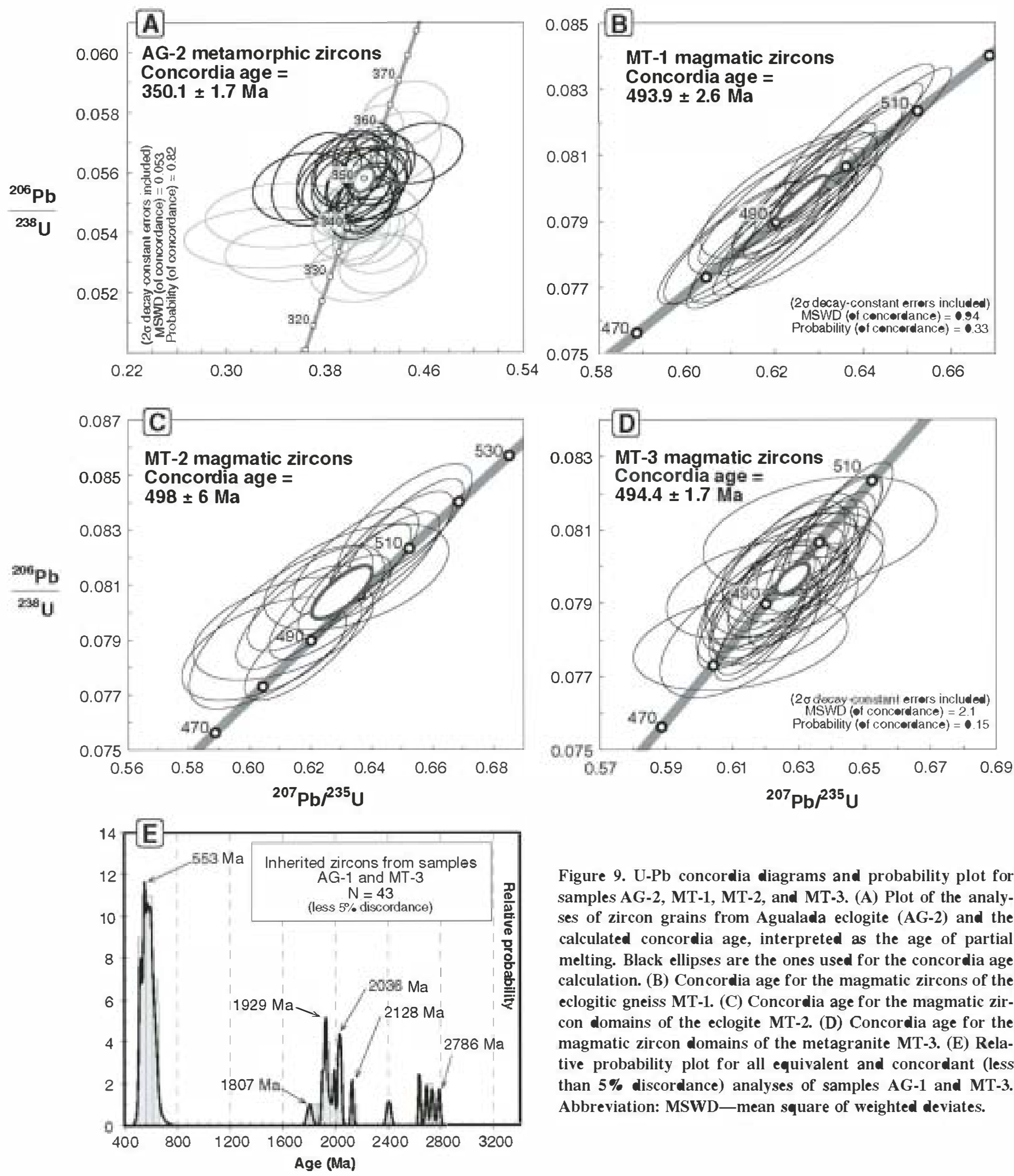

Figure 9. U-Pb concordia diagrams and probability plot for samples AG-2, MT-1, MT-2, and MT-3. (A) Plot of the analyses of zircon grains from Agualada eclogite (AG-2) and the calculated concordia age, interpreted as the age of partial melting. Black ellipses are the ones used for the concordia age calculation. (B) Concordia age for the magmatic zircons of the eclogitic gneiss MT-1. (C) Concordia age for the magmatic zircon domains of the eclogite MT-2. (D) Concordia age for the magmatic zircon domains of the metagranite MT-3. (E) Relative probability plot for all equivalent and concordant (less than 5\% discordance) analyses of samples AG-1 and MT-3. Abbreviation: MSWD-mean square of weighted deviates. 
(MT-2), we consider that this age is the best estimation for the age of the mafic-intermediate magmatism of the Malpica-Tui Unit.

Corona Texure Metagranites (Sample MT-3)

These rocks appear in the less deformed domains, and commonly the original igneous texture is preserved. The high-P event is only evident in the coronitic domains, where the most common texture is the growth of garnet coronas around biotite (Fig. 4G), accompanied rarely by the partial replacement of biotite by fine-grained phengite and rutile, and a variable degree of replacement of plagioclase by albite, clinozoisite, and phengite. In very few cases, the corona textures around biotite include jadeite (Gil Ibargucbi, 1995), although this mineral is more commonly found in associated finer graine rocks, such as aplitic veins.

The zircons separated from this sample are a homogeneous population of clear and goodquality crystals, idiomorphic and essentially prismatic, although some of them are less elongated and multifaceted. The CL patterns (Fig. 10) reveal a well-developed oscillatory zoning, more or less complex, with some runcations consistent with several stages of magmatic growth. Xenocrystic cores are abundant and, together with most of the rounded and multifaceted grains, are inherited. As in the internediatemafic eclogitic rocks, it seems that no zircon grew during the high-pressure event, but in this case it is perhaps less surprising, because metamorphic recrystallization is not complete, and probably there was not enough fluid released to promote new zircon growth. Of the more than 70 zircon grains analyzed, around half of the data form a coherent group that we interpret as magmatic ages, and the other half are inherited or represent mixtures with inherited components. We calculate a concordia age for the first group, excluding the analyses with more than $5 \%$ of discordance, of $494 \pm 2$ Ma (Fig. 9D). Alternatively, we calculated a robust median age using the Tuffzirc algoritlun (Ludwig, 2003), obtaining a similar result of $492 \pm 3$ Ma from a coherent group of 33 analyses. The older zircons are commonly xenocrystic cores or the rounded and multifaceted grains. The latter have a dark core surrounded by an oscillatory rim, being the older components in these dark cores (Fig. 10A). Three different age populations can be clearly distinguished, a Neoproterozoic one ranging between 540 and $650 \mathrm{Ma}$, a Paleoproterozoic one ranging between 1800 and $2125 \mathrm{Ma}$, and a Paleoproterozoic to Archean one ranging between 2405 and $2790 \mathrm{Ma}$ (Fig. 10D).

The Lu-Hf isotope analyses have been performe on 14 magmatic zircon and seven inherited cores (Fig. 7). Magmatic zircons from this

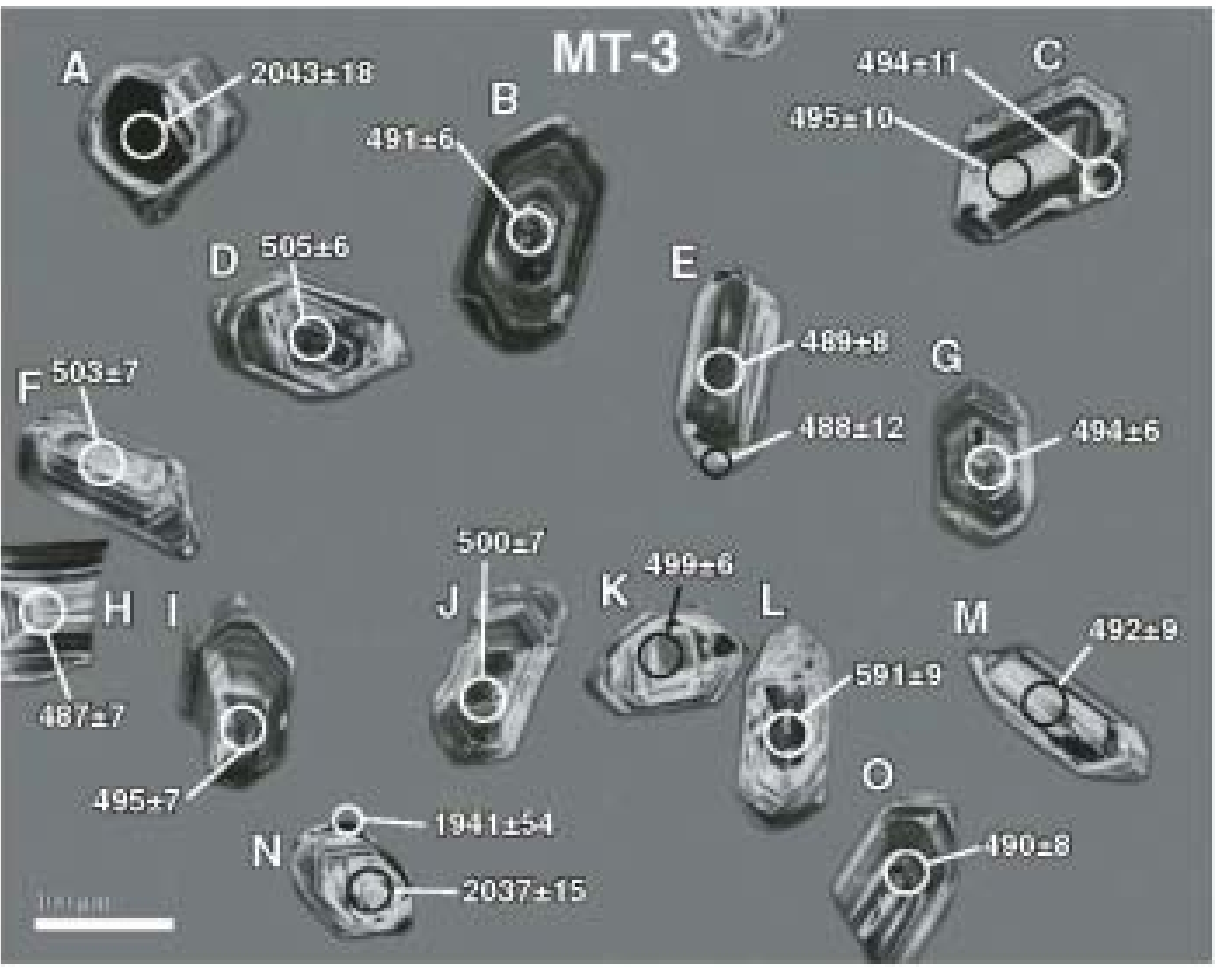

Figure 10. Cathodoluminescence images of zircons from a Malpica-Tui metagranite (MT-3). The laser spots are marked by open circles labeled with the ${ }^{206} \mathrm{~Pb} /{ }^{238} \mathrm{U}$ ages for young zircon domains and ${ }^{207} \mathrm{~Pb} /{ }^{206} \mathrm{~Pb}$ ages for older grains $(>1000 \mathrm{Ma}$ ) and their corresponding 20 errors. They show oscillatory zoning typical for igneous growth. Metamorphic overgrowth domains were not identified. In addition, examples of xenocrystic cores (A and L) and completely inherited old crystals $(\mathbf{N})$ are shown.

metagranite have a ${ }^{176} \mathrm{Hf} /{ }^{177} \mathrm{Hf}(\mathrm{t})$ of $0.282430 \pm$ 0.000026 (2 SD), which is as homogenous as the zircons from the Agualada felsic gneiss but considerably more radiogenic, which points to a more juvenile component in the parent magma of the metagranite. Inherited cores show a variable but less radiogenic Hf isotope composition than the magmatic cores. Considering that the latter represent the composition of the magma after assimilation of crustal material (= inherited zircon), the pristine magma must have had a considerably more juvenile $\mathrm{Hf}$ isotope composition.

\section{DISCUSSION AND CONCLUSIONS}

The Cambro-Ordovician Magmatism in the Basal Units

One of the major conclusions of this study is that the Cambro-Ordovician igneous activity represented by the two calc-alkaline and alkaline magmatic associations of the basal units corresponds to different magmatic events separated by ca. $20 \mathrm{Ma}$. Four samples of the calcalkaline association gave robust and consistent ages of 493-494 \pm 3 Ma obtained by two distinct analytical methods, whereas alkaline magmatism has been date by TIMS at $472 \pm 2 \mathrm{Ma}$ (Rodríguez et al., 2007; Fig. 1). The ages of inherite zircons, their variable ${ }^{176} \mathrm{Hf} /{ }^{177} \mathrm{Hf}$ isotope composition, and that of the igneous zircon $\left(\varepsilon \mathrm{Hf}_{493 \mathrm{Ma}}-0.5\right.$ to -5.5 ; see Table DR4 [footnote 1]) suggest that the parent magma from which the igneous zircon crystallized was formed by at least two components: (1) a heterogeneous crustal component, as indicated by the presence of inherite cores with crustal Hf isotope composition corresponding to mean crustal residence ages of 1.4-3.2 Ga (depleted mantle model ages, Table DR4 [footnote 1]), and (2) a more juvenile component. The latter component was perhaps a juvenile mantle-derived magma contaminated with significant amounts of crustal material, or a juvenile crustal component. Both scenarios fit well with the geodynamic models propose to explain the distribution of peri-Gondwanan terranes at the time of the Cambro-Ordovician boundary. Our new data contrast with a previous model of Rodríguez Aller (2005), who proposed that the two magmatic suites of the basal units (alkaline and calc-alkaline) were cogenetic, 
post-collisional suites. Instead we suggest that the Late Cambrian calc-alkaline magmatism is related to the waning stages of arc activity associated with the protracted history of Neoproterozoic-Cambrian subduction beneath the north Gondwanan margin. The imprints of this subduction-arc system are abundant calcalkaline volcanic rocks and cogenetic plutons, sedimentary rocks, and deformation associated with the opening and closing of arc-related basins (e.g., Murphy and Nance, 1989; Nance et al., 1991, 2002, 2008; Keppie et al., 2003; Murphy et al., 2004). Subsequently, the change in the tectonic regime from subduction to rifting in this part of the belt was marke by the eruption of alkaline volcanics and intrusion of associated plutons and A-type granitoids at the time of Early to Middle Ordovician boundary. CambrianLower Ordovician rifting of the northern margin of Gondwana is documented elsewhere and is widely believed to be related to the opening of the Rheic Ocean or equivalent basins and the drifting to the north of several peri-Gondwanan terranes, such as Avalonia, Carolina, and the upper units of the allochthonous complexes of Galicia and Portugal (Van Staal et al., 1998; Cocks and Torsvik, 2002; Stampfli and Borel, 2002; Gómez-Barreiro et al., 2006; Abati et al., 2007; Arenas et al., 2007). The alkaline and peralkaline rocks intrude the sedimentary rocks and the previously crystallized calc-alkaline plutons. Geochemical and structural data also support an extensional setting for alkaline magmatism, as does the identification of folded ring dikes in the Malpica-Tui Unit (Díez Fernández and Martínez Catalán, 2007). The superposition of both types of magmatism can be explained by rollback of a subducting slab that would produce oceanward migration of the related arc and the initiation of a backarc rifting. Thus, the location of the initial rifting could overlap part of the arc crust previously in ruded by calc-alkaline plutons, producing the spatial superposition of both magmatic associations (Fig. 11).

\section{Ages of Metamorphism}

The high-P lower allochthonous units of the European Variscan Belt represent a continental fragment that in some places, such as in the north part of the Malpica-Tui Unit, show ransitional to oceanic features (Rodríguezet al., 2003), and they have been interpreted as the most external edge of North Gondwana (Martínez Catalán et al., 1996, 1997; Arenas et al., 1997). The $372 \pm 3 \mathrm{Ma}$ age obtained from the metamorphic zircon rims of the Agualada orthogneiss constrains the age of subduction of this continental margin in westernmost Europe and is, although slightly older, consistent with $\mathrm{Ar}-\mathrm{Ar}$ and $\mathrm{Rb}-\mathrm{Sr}$

\section{W}

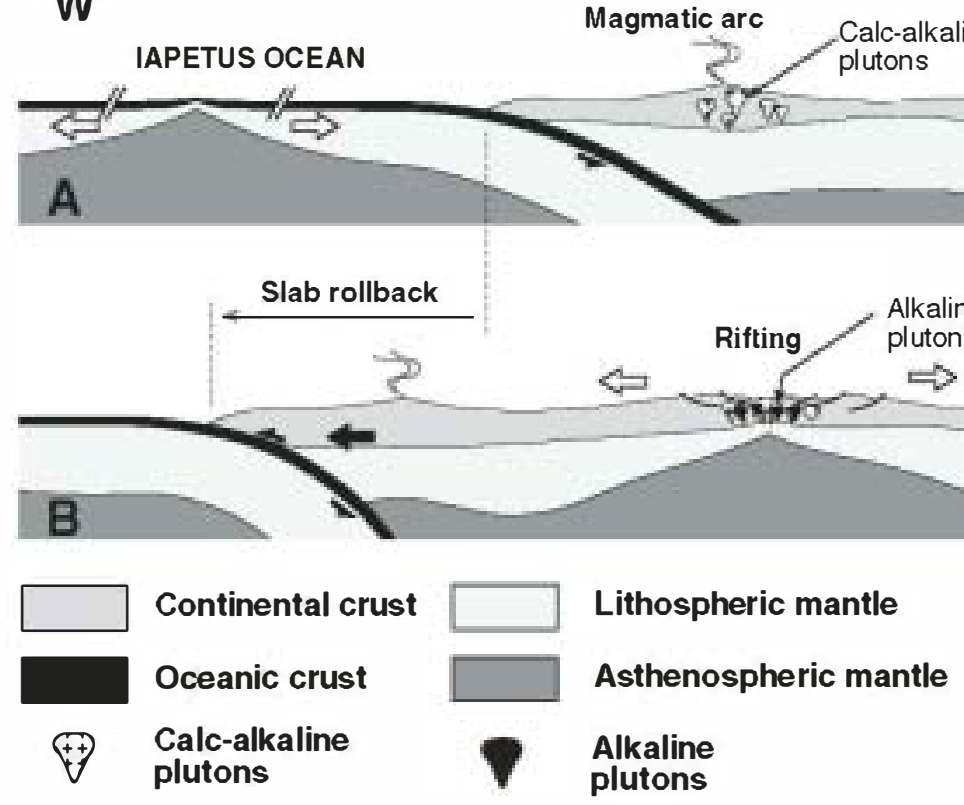

Calc-alkaline

GONDWANA

Figure 11. Proposed model for the evolution of magmatism in the basal units of the allochthonous complexes of NW Iberian Massif. The calc-alkaline association is related to an active plate margin in the north Gondwana margin at ca. $495 \mathrm{Ma}$ (A) evolving through a slab rollback process that produces the migration of the arc oceanward and the initiation of a backarc rift and concomitant alkaline magmatism that intrudes in the previous calcalkaline plutons at ca. $470 \mathrm{Ma}(\mathrm{B})$. The rift will progress to form the Rheic Ocean.

ages from high-pressure rocks of the same and equivalent units. The most precise previous ages were 355-370 Ma Ar-Ar ages, with a peak at $365 \mathrm{Ma}$ (Rodríguez et a1., 2003; Bosse et al., 2005). The similarity of U-Pb zircon and Ar-Ar age determinations suggests that the growth of the zircon rims is related to the high-P event, and that the U-Pb age presented here is the bestestimation of the timing of the peak eclogitic metamorphismin the basal units. This Late Devonian high-pressure and commonly low-temperature event can be found throughout the Variscan Belt of Europe. In southem Iberia, a tentative correlation can be made with the eclogites of the Évora Massif (Ossa-Morena Zone, Portugal), that have been dated at $371 \pm 17 \mathrm{Ma}(\mathrm{Sm}-\mathrm{Nd}$ on whole-rock garnet; Moita et al., 2005); in the Armorican Massif, the high-P metamorphism of equivalent units has been dated in the Île the Groix at $365 \pm 2 \mathrm{Ma}$ (Ar-Ar in phengites; Bosse et al., 2005) and in the Champtoceaux complex at $362 \pm 25$ (Sm-Nd; Bosse et al., 2000). In the easternmost European Variscan Massifs, in the Bohemian Massif, and the Carpathians, indirect evidence indicates a Late Devonian-Early Carboniferous age of metamorphism (Collins et al., 2000; Mazur et al., 2006; Balintoni et al., 2007). Taken together, these data suggest that the lower allochthonous terrane was a large continental piece that underwent an essentially synchronous subduction in early-Variscan times. However, more reliable and precise ages are required to evaluate possible diaclıronism of continental subduction.

Part of the exhumation path is constrained by the 351-346 Ma age of incipient partial melting in the Agualada Unit, marked by new zircon growth in the eclogites and monazite growth in the migmatitic paragneisses (Abati and Dunning, 2002). The mineralogy of the paragneisses and the enclosed mafic rocks limits melting to mid-crustal levels, in amphibolite facies conditions at 6-9 kbar (Arenas et al., 1997). Assuming a pressure peak of 20 kbar (Rodríguez Aller, 2005), an exhumation from 20 to $8 \mathrm{kbar}$ in $20 \mathrm{Ma}$ (from 372 to $351 \mathrm{Ma}$ ) gives an exhumation rate of $0.7 \mathrm{kbar} \mathrm{Ma}^{-1}$. This is an exremely slow exhumation rate for high-pressure rocks, where values in the range of 2-17 kbar $\mathrm{Ma}^{-1}$ are the most common according to wellconstrained natural examples and numerical thermal-mechanical models (e.g., Warren et al., 2008 and references therein). The exhumation of high- to ultrahigh-pressure rocks during the ransition from oceanic subduction to continental collision is believed to occur in two stages: an initial stage of rapid exhumation to mid-crustal levels controlled mainly by forced ascent due to 
buoyancy; and a second, slower stage controlled mainly by erosion (Warren et al., 2008). Therefore, it seems probable that the partial melting was triggere after the rapid exhumation stage, and after some time of residence in the middle crust. The stage of rapid exhumation and melting was favored by the underthrusting of a new crustal sheet (the parautochthon) below the basal units through the major Lalín-Forcarei thrust and the concomitant imbrication with a hot ultramafic sheet of the overlying ophiolites, as proposed by Martínez Catalán et al. (2002, 2007). The $S_{2}$ cleavage in the underlying parautochthon developed during the emplacement of the Lalín-Forcarei thrust at $340 \mathrm{Ma}$ $\left({ }^{4 \bullet} \mathrm{Ar} /{ }^{39} \mathrm{Ar}\right.$; Dallmeyer et al., 1997).

\section{Felsic Igneous Rocks and the Zircon Sources}

The inherited zircons from granitic rocks can represent either restitic crystals from the source area where the melts were extracted, or xenocrysts assimilate by the interaction with the wall rock during the ascent and emplacement of the magmas. Many studies have shown a common correlation between inherited zircon ages in granites and the age of zircon in their source rocks (Williams et al., 1991; Fioretti et al., 2005; Smyth et al., 2007; Nelson, 2008). Therefore, the ages of inherited zircons can provide useful information on the crust from which granites were generated, and also they may preserve provenance information of the sedimentary rocks they intrude, in an analogous way to that of detrital zircons. Due to the lack of basement exposures in the Iberian Massif, and their scarcity in the whole peri-Gondwanan terrane, the patterns of inherited zircons in granitic rocks from this area are especially relevant. Undisputed basement rocks occur only as dispersed and small outcrops of gneiss in the North Arnnorican and Bohemian massifs. These are the ca. $2.1 \mathrm{Ga}$ gneiss of Icart and Svetlik (Kröner et al., 1988; Samson and D'Lemos, 1998) and the ca. $1.38 \mathrm{Ga}$ Dobra orthogneiss (Gebauer and FriedI, 1993).

Plotting all concordant xenocrystic zircon ${ }^{20} \mathrm{~Pb} /{ }^{206} \mathrm{~Pb}$ ages of the two samples of felsic rocks from the basal units on a relative probability diagram (Fig. 6D) constrains the possible source areas. The most striking features are the lack of Mesoproterozoic zircons and the peak age frequencies typical of the West African Craton: the most significant group is $550-600 \mathrm{Ma}$ (Pan-African Orogeny), a second Paleoproterozoic group of 1.8-2.1 Ga (Eburnean Orogeny), only one zircon at ca. $2.4 \mathrm{Ga}$, and minor Archean peaks between 2.6 and $2.8 \mathrm{Ga}$ (Liberian Orogeny). Assuming that at least part of the in- herited zircons represents restitic crystals, this age signature strongly supports a West African Craton origin for the basal units of NW Iberian Massif. If some contamination with the wall sedimentary rocks had occurred, this signature would imply the same source area for the sedimentary rocks. The Hf isotopic composition of the inherited zircons indicates that the younger ones (Neoproterozoic) formed during the recycling of older crust, whereas the older ones with near zero or slightly positive $\varepsilon \mathrm{Hf}$ represent less reworked crust formation and direct exraction from the mantle, that is, formation of juvenile continental crust.

\section{ACKNOWLEDGMENTS}

This study was financially suppørted through projects CGL2004-4306-C2/BTE of Spanish Di rección General de Investigación and prøject $\mathrm{CM}$ UCM-910129 •f the Comunidad de Madrid. The SIMS analyses were perf $\bullet$ rmed in the NORDSIM facility of Steckhølm thrøugh a SYNTHESIS prøject of the European Union (SE-TAF-1571). We would like to thank Fernando Corfu, Stephen Jøhnstøn, and Mark Schmitz f $\bullet$ their cønstructive and helpful reviews, which significantly improved the quality of the paper.

\section{REFERENCES CITED}

Abati, J., 2002, Petrología metamórfica y geocronología de la unidad culminante del Complejo de Ordenes en la región de Carballo (Galicia, NW del Macizo Ibérico) Sada-A Coruña, Serie Nova Terra, Ediciós do Castro, v. $20,269 \mathrm{p}$.

Abati, J., and Dunning, G.R., 2 2, Edad U-Pb enmonacitas y rutilos de los paragneisses de la Unidad de Agualada (Comple jo de Ordenes, NW del Macizo Ibérico): Geogaœta, v. 32, p. 95-98.

Abati, J., Dunning, G.R., Arenas, R., Díaz García, F. González Cuadra, P., and Martínez Catalán, J.R. 1999, Early Ordovician orogenic event in Galicia (NW Spain): Evidence from U-Pb ages in the uppermost unit of the Ordenes Complex: Earth and Planetary Scienœ Letters, v. 165 , p. 213-228, doi: 10.1016 S॰12-821X(98) 268-4

Abati, J., Arenas, R., Martínez Catalán, J.R., and Díaz García, F., 2003, Anticlockwise P-T path of granulites from the Monte Castelo Gabbro (Órdenes Complex, NW Spain): Joumal of Petrology, v. 44, p. 305-327, doi: $10.1093 /$ petrology/44.2.305

Abati, J., Castiñeiras, P., Arenas, R., Fernández Suárez, F.J., Gómez Barreiro, J., and Wooden, J.L., 2007, Using SHRIMP zirøon dating to unravel tectonothernal events in arc environments: The early Paleozoic arc of NW Iberia revisited: Terra Nova, v. 19, p. 432-439, doi: $10.1111 / \mathrm{j} .1365-3121.2007 .00768 . x$.

Alcock, J., Arenas, R., and Martínez Catalán, J.R., 2005, Shear stress in subducting continental margin from high-pressure, moderate-temperature metamor phism in the Ordenes Complex, Galicia, NW Spain Tectonophysics, v. 397, p. 181-194, doi: $10.1016 /$ j.tecto.2004.11.009.

Arenas, R., Rubio Pascual, F.J., Díaz García, F., and Martínez Catalán, J.R., 1995, High-pressure micro inclusions and development of an inverted metamorphic gradient in the Santiago Schists (Ordenes Complex, NW Iberian Massif, Spain): Evidence of subduction and syncollisional decompression: Journal of Metamorphic Geology, v. 13, p. 141-164, doi 10.1111/j.1525-1314.1995.tb@211.x.

Arenas, R., Abati, J., Martínez Catalán, J.R., Díaz García, F., and Rubio Pascual, F.J., 1997, P-T evolution of eclogites from the Agualada unit (Ordenes Complex,
NW Iberian Massif, Spain): Implications for crustal subduction: Lithos, v. 40 , p. 221-242, doi: 10.1016 S1024-4937(97) $10029-7$

Arenas, R., Martínez Catalán, J.R., Sánchez Martínez, S., Díaz Garcia, F., Abati, J., Fernández Suárez, J., Andonaegui, P., and Gómez-Barreiro, J., 2007 , Paleozoic ophiolites in the Variscan suture of Galicia (northwest Spain): Distribution, characteristics and meaning, in Hatcher, R.D., Jr., et al., eds., 4-D framework of continental crust: Geological Society of America Memoir, v. 200, p. 425-444.

Baldwin, J.A., Bowring, S.A., Williams, M.L., and Williams, I.S., 2 4, Eclogites of the Snowbird tec tonic zone: Petrological and U-Pb geochronological evidenœ for Paleoproterozoic high-pressure metamorphism in the western Canadian Shield: Contributions to Mineralogy and Petrology, v. 147 , p. 528-548, doi: 10.1007/s 00410-04-0572-4.

Balintoni, I.C., Balica, C., Zaharia, L., Cliveti, M., Chen, F., Hann, H.P., and Li, L.Q., 2007, The age of the Variscan suture in the Apuseni Mountains, Romania, as revealed by LA-ICP-MS zirøon dating, in Proceedings, American Geophysical Union Fall Meeting Abstracts, p. A1139.

Bosse, V., Feraud, G., Ruffet, G., Ballévre, M., Peucat, J.J., and De Jong, K., 2000, Late Devonian subduction and early orogenic exhumation of eclogite-facies rocks from the Champtoceaux Complex (Variscan belt, France): Geological Jonrnal, v. 35, p. 297-325.

Bosse, V., Feraud, G., Ballevre, M., Peucat, J.-J., and Corsini, M., 2005, Rb-Sr and ${ }^{40} \mathrm{Ar} /{ }^{39} \mathrm{Ar}$ ages in blue schists from the Ile de Groix (Armorican Massif, France): Implications for closure mechanisms in isotopic systems: Chemical Geology, v. 22, no. 1-2, p. $21-45$, doi: $10.1016 /$ j.chemgeo.205. 2.॰19.

Cocks, L.R.M., and Torsvik, T.H., 202, Earth geography from 500 to 400 million years ago: A faunal and palaeo magnetic review: The Geological Society of London, v. 159,p. 631-644, doi: 10.1144/0016-764901-118.

Collins, A.S., Kryza, R., and Zalasiewicz, J., 2000, Macrofabric fingerprints of Late Devonian-Early Carboniferous subduction in the Polish Variscides, the Kaczawa complex, Sudetes: Jonrnal of the Geological Society, v. 157, p. $283-288$.

Corf 1 , F., Hanchar, J.M., Hoskin, P.W. ., and Kinny, P.D., 2003a, Atlas of zircon textures: Reviews in Min eralogy and Geochemistry, v. 53 , p. $469-5 \mathbf{\omega}$, doi 10.2113/0530469

Corfı, F., Ravna, E.J.K., and Kullerud, K., 2003b, A Late Ordovician $\mathrm{U}-\mathrm{Pb}$ age for the Troms $\varnothing$ Nappe eclogites, Uppermost allochthon of the Scandinavian caledo nides: Contributions to Mineralogy and Petrology, v. 145 , p. $502-513$, doi: $10.107 / \mathrm{s} \bullet 410-003-466-x$.

Dallıneyer, R.D., Martínez Catalán, J.R., Arenas, R., Gil Ibarguchi, J.I., Gutiérrez Alonso, G., Farias, P., Aller, J., and Bastida, F., 1997, Diachronous Variscan tectonothernal activity in the NW Iberian Massif: Evidence from ${ }^{40} \mathrm{Ar} /{ }^{39} \mathrm{Ar}$ dating of regional fabrics: Tectonophysics, v. 277 , p. 307-337, doi: $10.1016 /$ S०040-1951(97) $035-8$

Díez Fernández, R., and Martínez Catalán, J.R., 2007, Variscan recumbent holding of Ordovician plutons in the Malpica-Tui Unit (NW Iberia), in Arenas, R., Martínez Catalán, J.R., and Abati, J., eds., The rootless Variscan suture of NW Iberia (Galicia, Spain): Field trip guide and conferenee abstracts: International Geological Correlation Programme 497: The Rheic Ocean: Its origin, evolution and correlatives: Publicaciones del Instituto Geológiøo y Minero de España, p. 148-149.

Fernández Suárez, J., Arenas, R., Abati, J., Martínez Catalán, J.R., Whitehouse, M.J., and Jeffries, T., 2007, U-Pb chronometry of polymetamorphic high-pressure granulites: An example from the allochthonous terranes of the NW Iberian Variscan belt, in Hatcher, R.D., Jr., ed 4-D framework of continental crust: Geological Society of America Memoir, v. 200, p. 469-488.

Fioretti, A.M., Capponi, G., Black, L.P., Vame, R., and Visona, D., 2ஸ5, Surgeon island granite SHRIMP zir con ages: A clue for the Cambrian tectonic setting and evolution of the Palaeopacific margin of Gondwana (northern Victoria Land, Antarctica): Terra Nova, v. 17, p. 242-249, doi: $10.1111 /$ j. 1365-3121.2005.00606.x. 
Frei, D., and Gerdes, A., 2ஸs, Accurate and precise insitu zircon $\mathrm{U}-\mathrm{Pb}$ age dating with high spatial resolution and high sample throughput by automated LA-SF-ICP-MS: Chemical Geology, doi: 10.1016/ j.chemgeo.2008.07.025

García Garzón, J., de Pablo Maciá, J.G., and Llamas Borrajo, J.F., 1981, Edades absolutas obtenidas mediante el método $\mathrm{Rb} / \mathrm{Sr}$ en dos cuerpos de ortoneises en Galicia Occidental: Boletín Geológiøo y Minero, v. 92, p. 463-466.

Gebaner, D., and Friedl, G., 1993, A 1.38 Ga protolith age for the Dobra orthogneiss (Moldanubian zone of the southern Bohemian massif, NE Austria): Evidence from ion-microprobe (SHRIMP)-dating of zircon: European Jonrnal of Mineralogy, v. 5, p. 115.

Geisler, T., Schaltegger, U., and Tomaschek, F., 2007, Re-equilibration of zircon in aqueous fluids and melts: Elements, v. 3, no. 1, p. 43-50, doi: 10.2113 / gselements.3.1.43.

Gerdes, A., and Zeh, A., 2006, Combined U-Pb and $\mathrm{Hf}$ isotope LA-(MC)-ICP-MS analyses of detrital zircons: Comparison with SHRIMP and new constraints for the provenance and age of an Armorican metasediment in Central Germany: Earth and Planetary Science Letters, v. 249 , p. 47-61, doi: $10.1016 /$ j.epsl.206.06.039.

Gerdes, A., and Zeh, A., 2 208 , Zirøon formation versus zircon alteration-New insights from $\bullet$ mbined U-Pb and Lu-Hf in-situ LA-ICP-MS analyses, and ensequenœs for the interpretation of Archean zircon from the Central Zone of the Limpopo Belt: Chemical Geology, doi: 10.1016/j.chemgeo.2008.03.005.

Gil Ibarguchi, J.I., 1995, Petrology of jadeite-metagranite and associated orthogneiss from the Malpica-Tuy allochthon (northwest Spain): European Joumal of Mineralogy, v. 7, p. 403-415.

Gil Ibarguchi, I., and Ortega Gironés, E., 1985, Petrology, structure and geotectonic implications of glaucophane-bearing eclogites and related rocks from the Malpica-Tuy (MT) Unit, Galicia, northwest Spain: Chemical Geology, v. 50, p. 145-162, doi: 10.1016/0009-2541(85)90117-2.

Gómez-Barreiro, J., Martínez Catalán. J.R., Arenas, R., Castiñeiras, P., Abati, J., Díaz García, F., and Wijbrans, J.R., 2006, Tectonic evolution of the upper allochthon of the Ordenes Complex (northwestern Iberian Massif): Structural constraints to a polyorogenic periGondwanan terrane, th Linnemann, U., et al., eds., The evolution of the Rheic Acean: From AvalonianCadomian active margin to Alleghenian-Variscan collision: Geological Society of America Special Paper, v. 423 , p. $315-332$

Harley, S., Kelly, N.M., and Möller, A., 2007, Zircon behaviour and the thernal histories of monntain chains: Elements, v. 3, p. $25-30$, doi: $10.2113 /$ gselements.3.1.25

Hoskin, P.W. ., 2 1 , Pattems of chaos: Fractal statistics and the oscillatory chemistry of zireon: Geochimica et Cosmochimica Acta, v. 64, p. 1905-1923, doi: 10.1016/Sผ 16-7037(ט) $00330-6$

Hoskin, P.W. ., and Black, L.P., 2ஸ, Metamorphic zircon fornation by solid state re-crystallization of protolith igneous zircon: Jonmal of Metamorphic Geology, v. 18, p. 423-439, doi: 10.1046/j.1525-1314.2000.0266.x.

Jackson, S.E., Pearson, N.J., Grif $\mathrm{m}$, W.L., and Belousova, E.A., 204, The application of laser ablationinductively conpled plasma-mass spectrometry to in situ U-Pb zircon geochronology: Chemical Geology, v. 211, p. 47-69, doi: 10.1016/j.chemgeo.204.06.017.

Janoušek, V., Gerdes, A., Vrána, S., Finger, F., Erban, V., Friedl, G., and Braithwaite, C.J.R., 2006, Low pressure granulites of the Lišiov Massif, southem Bohemia: Viséan metamorphism of Late Devonian plutonic arc rocks: Journal of Petrology, v. 47, p. 705-744, doi: 10.1093/petrology/egie91.

Keppie, J.D., Nanœe, R.D., Murphy, J.B., and Dostal, J., 2003, Tethyan, Mediterranean, and Pacific analogues for the Neoproterozoic-Paleozoic birth and development of peri-Gondwanan terranes and their ransfer to Laurentia and Laurussia: Tectonophysics, v. 365, p. 195-219, doi: 10.1016/S1040-1951(@3) $1037-4$

Kröner, A., Wendt, I.J., Liew, T.C., Compston, W., Todt, W., Fiala, J., Vankova, V., and Vanek, J., 1988, U/Pb zircon and Sm-Nd model ages of high grade Moldanubian sediments, Bohemian massif, Czechoslovakia: Contributions to Mineralogy and Petrology, v. 99, p. 257 266, doi: 10.1007, BFW371466.

Kryza, R., Muszynski, A., and Vielzeuf, D., 1990 Glaucophane-bearing assemblage overprinted by greenschist-facies metamorphism in the Variscan Kaczawa complex, Sudetes, Poland: Joumal of Metamorphic Geology, v. 8, no. 3, p. 345-355, doi: 10.1111/ j. 1525-1314.1990.tb $4077 . x$

López Carmona, A., 207, Evolución metamórfica de los esquistos de alta presión de Ceán (Unidad de MalpicaTui, NW del Macizo Ibérico) [M.S. thesis]: Universi dad Complutense de Madrid.

López Carnona, A., Abati, J., and Reche, J., 2007, Evolu ción metamórfica de los esquistos de AP/BT de Ceán (Unidad de Malpica-Tui, NW del Macizo Ibérico): Geogaceta, v. 43, p. 3-6.

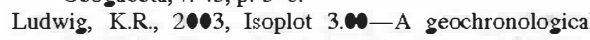
toolkit for Microsoft Excel: University of Califormia Berkeley Geochronology Center Special Publication, no. $4,70 \mathrm{p}$

Martínez Catalán, J.R., Arenas, R., Díaz García, F., Rubio Pascual, F.J., Abati, J., and Marquínez, J., 1996 Variscan exhumation of a subducted Paleozoic continental margin: The basal units of the Ordenes Complex, Galicia, NW Spain: Tectonics, v. 15, p. 106 121, doi: $10.1029 / 95 \mathrm{TC} 2617$

Martínez Catalán, J.R., Arenas, R., Díaz García, F., and Abati, J., 1997, Variscan acretionary complex of northwest Iberia: Terrane correlation and succession of tectonothermal events: Geology, v. 25, p. 1103-1106, doi: $1 \bullet .113 \bullet / \bullet 091-7613(1997) 25<11 \bullet 3: \mathrm{VACONI}>$ 2.3.C 2 .

Martínez Catalán, J.R., Díaz García, F., Arenas, R., Abati, J., Castiñeiras, P., González Cuadra, P., Gómez Barreiro, J., and Rubio Pascual, F., 2002, Thrust and detach ment systems in the Ordenes Complex (northwestern Spain): Implications for the Variscan-Appalachian geodynamics, in Martínez Catalán, J.R., et al., eds., Variscan-Appalachian dynamics: The building of the late Paleozoic basement: Geological Society of America Special Paper, v. 364, p. 163-182.

Martínez Catalán, J.R., Arenas, R., Díaz García, F., Gómez Barreiro, J., GonzálezCuadra, P., Abati, J., Castiñeiras, P., Fernández-Suárez, J., Sánchez Martínez, S. Andonaegui, P., Gónzalez Clavijo, E, Díez Montes, A., Rubio Pascual, F.J., and Valle Aguado, B., 2ஸ7, Space and time in the tectonic evolution of the northwestern Iberian Massif: Implications for the comprehension of the Variscan belt, in Hatcher, R.D., et al., eds., 4-D framework of entinental crust: Geological Society of America Memoir, v. 2๑, p. 4๒3-423.

Mazur, S., Dunlap, W.J., Tumiak, K., and Oberc-Dziedzic, T., 2006, Age constraints for the thernal evolution and erosional history of the central European Variscan belt: New data from the sediments and basement of the Carbonif erous foreland basin in western Poland: The Geological Society of London, v. 163, p. 1011-1024, doi: 10.1144/0016-76492004-170

Mezger, K., and Krogstad, E.J., 1997, Interpretation of discordant $\mathrm{U}-\mathrm{Pb}$ zireon ages-An evaluation: Jour nal of Metamorphic Geology, v. 15, p. 127-140, doi 10.1111/j.1525-1314.1997.00008.x.

Moita, P., Munhá, J.M., Fonseca, P.E., Pedro, J., Tassinari, C.C.G., Araíijo, A., and Palacios, T., 2005, Phase equilibria and geochronology of Ossa-Morena eclogites, in Proceedings, XIV semana de Geoquímica, Universidade de Aveiro.

Murphy, J.E., and Nanœe, R.D., 1989, Model for the evolution of the Avalonian-Cadomian belt: Geology, v. 17, p. $735-738$, doi: $10.1130 / 0091-7613(1989) 17$ $<$ 735:MFIEOT $>2.3$.C ; 2

Murphy, J.B., Pisarevsky, S.A., Nanœ, R.D., and Keppie, J.D., 2004, Neoproterozoic-Early Paleozoic evolution of peri-Gondwanan terranes: Implications for Laurentia-Gondwana connections: International Journal of Earth Sciences, v. 93, p. 659-682, doi: $10.1007 /$

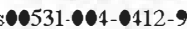

Nance, R.D., Murphy, J.B., Strachan, R.A., D'Lemos, R.S and Taylor, G.K., 1991, Late Proterozoic tectonostratigraphic evolution of the Avalonian and Cadomian terranes: Precambrian Research, v. 53, p. 41-78, doi: 10.1016/0301-9268(91)90005-U.

Nance, R.D., Murphy, J.B., and Keppie, J.D., 2002, Cordilleran model for the evolution of Avalonia: Tectonophysics, v. 352 , p. 11-32, doi: 10.1016 S0040-1951(12) 1801-7.

Nance, R.D., Murphy, J.B., Strachan, R.A., Keppie, J.D. Gutiérrez-Alonso, G., Fernández-Suárez, J., Qnesada, C., Linnemann, U., D'Lemos, R., and Pisarevsky, S.A., 2008, Neoproterozoic-early Palaeozoic tectonostratigraphy and palaeogeography of the peri-Gondwanan terranes: Amazonian versus West African ennections, in Ligelois, J.P., and Ennih, N., eds., The boundaries of the West African craton: The Geological Society of London, Special Publication, v. 297, p. 348-383.

Nelson, D.R., 208, Geochronology of the Archean of Australia: Australian Journal of Earth Sciences, v. 55, p. 779-793, doi: $10.1080 / 0812090802094135$.

Pidgeon, R.T:, 1992, Recrystallisation of oscillatory zoned zirøon: Some geochronological and petrological im plications: Contributions to Mineralogy and Petrology, v. 110, p. 463-473, doi: $10.1097 / \mathrm{BF} 0344081$

Pin, C., Ortega Cuesta, L.A., and Gil Ibarguchi, J.I., 1992 Mantle-derived, early Paleozoic A-type metagranitoids from the NW Iberian Massif: Nd isotope and trae element constraints: Bulletin de la Société Géologique de France, v. 163 , p. 483-494.

Ribeiro, M.L., and Floor, P., 1987, Magmatismo peralcalino no Maciø̧o Hespériø: Sua distribuçäo e significado geodinámico, in Bea, F., et al., eds., Geología de los granitoides y rocas asociadas del Macizo Hespériø: Madrid, Rueda, p. 211-221.

Rodríguez, J., Cosca, M.A., Gil Ibarguchi, J.I., and Dallmeyer, R.D., 2003, Strain partitioning and preservation of ${ }^{40} \mathrm{Ar} /{ }^{39} \mathrm{Ar}$ ages during Variscan exhuma tion of a subducted crust (Malpica-Tui complex, NW Spain): Lithos, v. 70, p. 111-139, doi: 10.1016 S1024-4937(13)0095-1

Rodrígnez, J., Paquette, J.L., and Gil Ibarguchi, J.I., 2007, $\mathrm{U}-\mathrm{Pb}$ dating of Coger Ordovician alkaline magmatism in the Gondwana margin (Malpica-Tui Complex, Ibe rian Massif): Latest continental events before ocanic spreading, in Arenas, R., Martínez Catalán, J.R., and Abati, J., eds., The rootless Variscan suture of NW Iberia (Galicia, Spain): Field trip guide and conference abstracts: International Geological Correlation Programme 497, The Rheic Acean: Its origin, evolution and correlatives: Publicaciones del Instituto Geológico y Minero de España, p. 163-164.

Rodríguez Aller, J., 2ஸ5, Recristalización y deformación de litologías supracorticales sometidas a metamorfismo de alta presión (Complejo de Malpica-Tuy, No de Macizo Ibérico): A Coruña, Laboratorio Xeolóxico de Laxe, Nova Terra, v. 29, 572 p.

Rubatto, D., 2002, Zircon traœ element geochemistry: Partitioning with garnet and the link between $\mathrm{U}-\mathrm{Pb}$ ages and metamorphism: Chemical Geology, v. 184, p. 123 138, doi: $10.1 \bullet 16 /$ S $109-2541(\bullet 1) \bullet 0355-2$

Rubatto, D., Gebauer, D., and Compagnoni, R., 1999,Dating of eclogite facies zircons: The age of Alpine metamorphism in the Sesia-Lanzo Zone (western Alps): Earth and Planetary Scienœ Letters, v. 167, p. 141-158, doi 10.1016/Sผ12-821X(99)ஸे31-X

Rubio Pascual, F.J., Arenas, R., Díaz García, F', Martíne Catalán, J.R., and Abati, J., 2002, Eclogites and eclogite amphibolites from the Santiago Unit (Ordenes Com plex, NW Iberian Massif, Spain): A case study of contrasting high-pressure metabasites in a contex of crustal subduction, in Martínez Catalán, J.R., et al., eds., Variscan-Appalachian Dynamics: The building of the Late Paleozoic basement: Geological Society of America, Special Paper, v. 364, p. 105-124.

Samson, S.D., and D'Lemos, R.S., 1998, U-Pb geochemistry and $\mathrm{Sm}-\mathrm{Nd}$ isotopic composition of Proterozoic gneisses, Channel Islands, United Kingdom: The Geo logical Society of London, v. 155, p. 609-618, doi: 10.1144/gs jgs. 155.4 .0609

Santos Zalduegui, J.F., Schärer, U., and Gil Ibarguchi, J.I., 1995, Isotope constraints on the age and origin of mag matism and metamorphism in the Malpica-Tuy allochthon, Galicia, NW Spain: Chemical Geology, v. 121, p. 91-103, doi: 10.1016/009-2541(94)00123-P 
Smyth, H.R., Hamilton, P.J., Hall, R., and Kinny, P.D., 2œ7, The deep crust beneath island arcs: Iuherited zireons reveal a Gondwana continental fragment beneath East Java, Iudonesia: Earth and Planetary Science Letters, v. 258 , p. $269-282$, doi: $10.1016 /$ j.epsl.207.03.044.

Staœy, J.S., and Kramers, J.D., 1975, Approximation of terrestrial lead isotope evolution by a two-stage model: Earth and Planetary Science Letters, v. 26, p. 207-221, doi: 10.1016/0012-821X(75)90088-6.

Stampfli, G.M., and Borel, G.D., 2002, A plate tectonic model for the Paleozoic and Mesozoic constrained by dynamic plate boundaries and restored synthetic omeanic isochrones: Earth and Planetary Science Letters, v. 196, p. 17-33, doi: $10.1016 /$ SN12-821X(ט1) 0588-X

Strachan, R.A., Nutman, A.P., and Friderichsen, J.D., 1995 , SHRIMP U-Pb geochronology and metamorphic history of the Smallef jord sequence, NE Greenland Caledonides: The Geological Society of London, v. 152, p. 779-784, doi: 10.1144/gsjgs.152.5.0779.

van Calsteren, P.W.C., Boelrijk, N.A.I.M., Hebeda, E.H., Priem, H.N.A., Den Tex, E., Verdurnen, E.A.T.H., and Verschure, R.H., 1979, Isotopic dating of older elements (including the Cabo Ortegal mafic-ultramafic complex) in the Hercynian Orogen of NW Spain: Manifestations of a presumed Early Paleozoic mantle plume: Chemical Geology, v. 24, p. 35-56, doi 10.1016/0099-2541(79)90011-1.

van Staal, C.R., Dewey, J.F., MacNiocaill, C., and McKerrow, S., 1998, The Cambrian-Silurian tectonic evolution of the northern Appalachians: History of a complex, southwest Pacific type segment of Iapetus, in Blundell, D.J., and Scott, A.C., eds., Lyell: The past is the key to the present: The Geological Society of London, Special Publication, v. 143, p. 199-242.

Vavra, G., and Schaltegger, U., 1999, Post-granulite facies monazite growth and rejuvenation during Permian to Lower Jurassic thermal and fluid events in the Ivrea Zone (Southem Alps): Contributions to Mineralogy and Petrology, v. 134, p. 405-414, doi: 10.107 s00410050493.

Warren, C.J., Beaumont, C., and Jamieson R.A., 2008, Modelling tectonic styles and ultra-high pressure (UHP) rock exhumation during the transition from oeanic subduction to continental collision: Earth and Planetary Science Letters, v. 267, p. 129-145.

Whitehouse, M.J., Kamber, B., and Moorbath, S., 1999 Age significance of $\mathrm{U}-\mathrm{Th}-\mathrm{Pb}$ zireon data from early Archaean rocks of west Greenland-A reassessment based on combined ion-microprobe and imaging studies: Chemical Geology, v. 160, p. 21-224, doi: 10.1016/S109-2541(99)00066-2.

Williams, I.S., Chappell, B.W., Chen, Y.D., and Crook, K.A.W., 1991, Inherited and detrital zireons-Vital clues to the granite protoliths and early igneous history of sontheastern Australia, in Chappell, B.W., ed., Second Hutton symposium on granite and related rocks: Canberra, Australia, 503 p. 